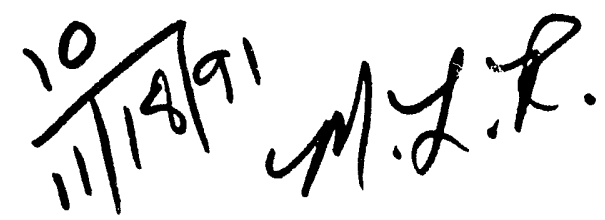

(1)

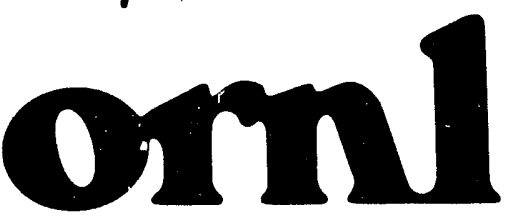

\section{OAK RIDGE \\ NATIONAL \\ LABORATORY}

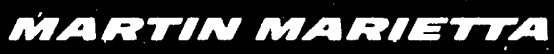

\title{
Criticality Safety Review of 2 1/2-, 10-, and 14-Ton UF 6 Cylinders
}

\author{
B. L. Broadhead
}

MANAGED BY

MARTIN MARIETTA ENERGY SYSTEMS, INC.

FOR THE UNITED STATES

UUEPAATTTMEENT ÜF ENEETEGYY 
This report has been reproduced directly from the best available copy.

Available to DOE and DOE contractors from the Office of Scientific and Technical Information, P.O. Box 62, Oak Ridge, TN 37831; prices available from (615) 576-8401, FTS 626-8401.

Available to the public from the National Technical Information Service, U.S. Department of Commerce, 5285 Port Royal Rd., Springfield, VA 22161.

This report was prepared as an account of work sponsored by an agency of the United States Government. Neither the United States Government nor any agency thereof, nor any of their employes, makes any warranty, express or implied, or assumes any legal liability or responsibility for the accuracy, completeness, or usefulness of any information, apparatus, product, or process disclosed, or represents that its t'se would not infringe privately owned rights. Reference herein to any specific commercial product, process, or service by trade name, trademark, manufacturer, or otherwise, does not necessarily constitute or imply its endorsement, recommendation, or favoring by the United States Government or any agency thereot. The views and opinions of authors expressed herein do not necessarily state or reflect those of the United States Government or any agency thereof. 


\title{
CRITICALITY SAFETY REVIEW OF 21/2-,
} 10-, AND 14-TON UF 6 CYLINDERS

\author{
B. L. Broadhead
}

Computing and Telecommunications Division at Oak Ridge National Laboratory

P.O. Box 2008

Oak Ridge, TN $37831-6370$

Date Published-October 1991

Prepared by the

OAK RIDGE NATIONAL LABORATORY

Oak Ridge, Tennessee 37831

managed by

MARTIN MARIETTA ENERGY SYSTEMS, INC.

for the

U.S. DEPARTMENT OF ENERGY

under contract DE-AC05-84OR21400

\section{MASTER}




\section{TABLE OF CONTENTS}

LIST OF FIGURES $\ldots \ldots \ldots \ldots \ldots \ldots \ldots \ldots \ldots \ldots \ldots \ldots \ldots$ iv

LIST OF TABLES $\ldots \ldots \ldots \ldots \ldots \ldots \ldots \ldots \ldots \ldots \ldots \ldots \ldots \ldots \ldots$

ACKNOWLEDGMENTS $\ldots \ldots \ldots \ldots \ldots \ldots \ldots \ldots \ldots \ldots \ldots \ldots \ldots \ldots \ldots \ldots \ldots$ vii

ABSTRACT $\ldots \ldots \ldots \ldots \ldots \ldots \ldots \ldots \ldots \ldots \ldots \ldots \ldots \ldots \ldots \ldots \ldots \ldots \ldots \ldots \ldots \ldots$

1. INTRODUCTION $\ldots \ldots \ldots \ldots \ldots \ldots \ldots \ldots \ldots \ldots \ldots \ldots \ldots \ldots \ldots \ldots$

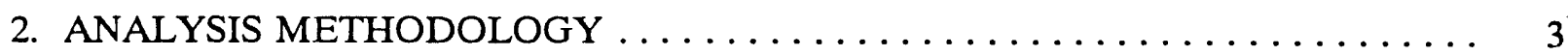

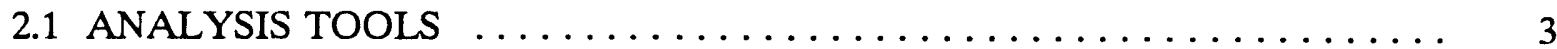

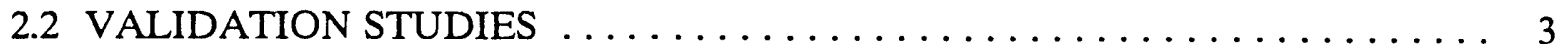

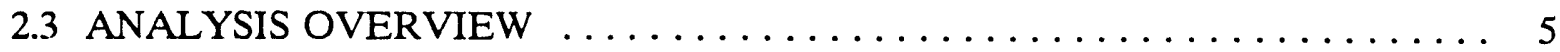

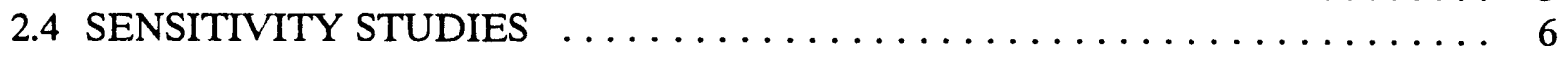

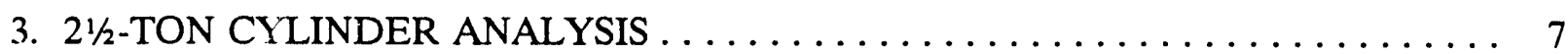

3.1 MODEL DESCRIPTION $\ldots \ldots \ldots \ldots \ldots \ldots \ldots \ldots \ldots \ldots \ldots \ldots \ldots \ldots$

3.2 ANALYSIS RESULTS FOR $21 \frac{1}{2}$-TON CYLINDER $\ldots \ldots \ldots \ldots \ldots \ldots \ldots \ldots$

3.2.1 Infinite Array Results without Overpacks . . . . . . . . . . . 13

3.2 .2 Infinite Array Results with Overpacks . . . . . . . . . . . . 13

3.2 .3 Single Unit Results . . . . . . . . . . . . . . . . . . 16

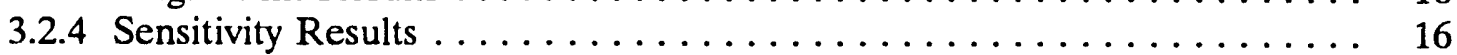

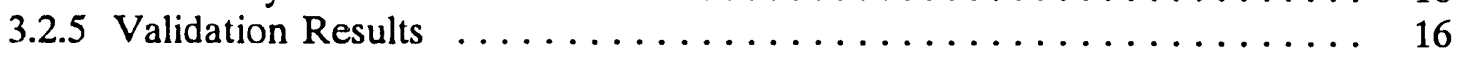

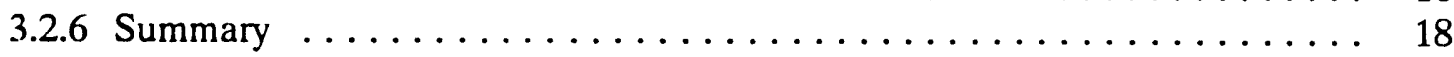

4. 10- AND 14-TON CYLINDER ANALYSIS $\ldots \ldots \ldots \ldots \ldots \ldots \ldots \ldots \ldots \ldots \ldots$

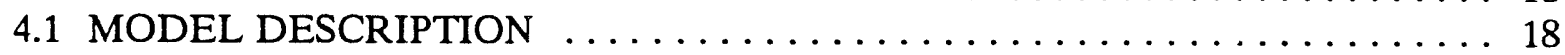

4.2 ANALYSIS RESULTS FOR 10- AND 14-TON CYLINDERS . . . . . . . 18

4.2.1 Infinite Array Results without Overpacks ............... 24

4.2 .2 Infinite Array Results with Overpacks . . . . . . . . . . . . . . . 24

4.2 .3 Single Unit Results . . . . . . . . . . . . . . . . . . . . . 29

4.2 .4 Sensitivity Results . . . . . . . . . . . . . . . . . . . . . . . 29

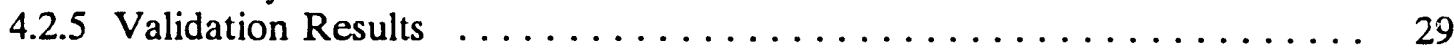

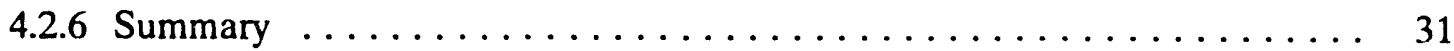

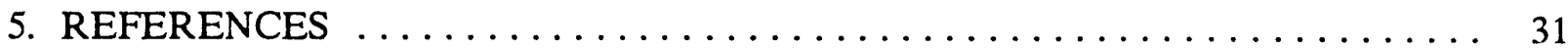




\section{LIST OF FIGURES}

Figure

Page

1. $\mathrm{k}_{\mathrm{eff}}$ versus average energy group causing fission (AEG) for 51 benchmark calculations . 4

2. Fuel locations analyzed to determine most reactive configuration for a

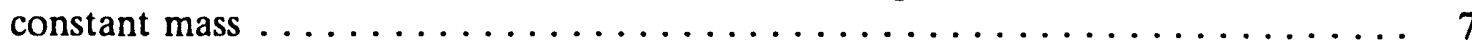

3. Model for $21 \frac{1}{2}$-ton cylinder without overpack $\ldots \ldots \ldots \ldots \ldots \ldots \ldots \ldots \ldots$

4. Model for DOT $21-$ PF-1 overpack $\ldots \ldots \ldots \ldots \ldots \ldots \ldots \ldots \ldots \ldots \ldots \ldots \ldots \ldots$

5. Plot of $k_{\text {eff }}$ versus water specific gravity for infinite array of $21 / 2$-ton $U_{6}$ cylinders (square-lattice, full-diameter model) $\ldots \ldots \ldots \ldots \ldots \ldots \ldots \ldots . \ldots \ldots$

6. Plot of $k_{\text {eff }}$ versus water specific gravity for infinite array of $21 / 2$-ton $U_{6}$ cylinders for original and $7 \%$ reduced pitch case $\ldots \ldots \ldots \ldots \ldots \ldots \ldots$

7. Model for 10 -ton cylinder without overpack $\ldots \ldots \ldots \ldots \ldots \ldots \ldots \ldots \ldots \ldots$

8. Model for 14 -ton cylinder without overpack $\ldots \ldots \ldots \ldots \ldots \ldots \ldots \ldots \ldots \ldots$

9. Model for Paducah Tiger overpack $\ldots \ldots \ldots \ldots \ldots \ldots \ldots \ldots \ldots \ldots \ldots \ldots \ldots$

10. Plot of $k_{\text {eff }}$ versus water specific gravity for infinite array of 14-ton $U_{6}$ cylinders (square-lattice, full-diameter model) $\ldots \ldots \ldots \ldots \ldots \ldots \ldots \ldots \ldots$

11. Plot of $k_{\text {eff }}$ versus water specific gravity for infinite array of 14-ton $\mathrm{UF}_{6}$ cylinders for original and $7 \%$ reduced pitch case $\ldots \ldots \ldots \ldots \ldots \ldots \ldots \ldots$

12. Plot of $k_{\text {eff }}$ versus water specific gravity for infinite arrays of $10-$ and 14-ton $\mathrm{UF}_{6}$ cylinders (square-lattice, full-diameter models) $\ldots \ldots \ldots \ldots \ldots$

13. Plot of $k_{\text {eff }}$ versus water specific gravity for infinite array of 10 -ton $\mathrm{UF}_{6}$ cylinders for original and $7 \%$ reduced pitch case . 


\section{LIST OF TABLES}

Table

Page

1. Constituent material mass and density $\left(2^{1 / 2}\right.$-ton cylinders $) \ldots \ldots \ldots \ldots \ldots \ldots \ldots$

2. Constituent material number density data $\left(2 \frac{1}{2}\right.$-ton cylinders $) \ldots \ldots \ldots \ldots \ldots \ldots$

3. Different types of calculations and their use in this study $\ldots \ldots \ldots \ldots \ldots \ldots$

4. Tabulated results for various models of $21 / 2$-ton cylinders $\ldots \ldots \ldots \ldots \ldots \ldots \ldots$

5. Constituent material mass and density data (10- and 14-ton cylinders) $\ldots \ldots \ldots 23$

6. Constituent material number density data $(10-$ and 14 -ton cylinders $) \ldots \ldots 23$

7. Tabulated results for various models of 10 - and 14 -ton cylinders $\ldots \ldots \ldots \ldots$ 


\section{ACKNOWLEDGMENTS}

The author wishes to acknowledge the help and guidance given by H. R. Dyer and C. V. Parks in support of this work. Also, appreciation is expressed to C. M. Hopper and H. R. Dyer for their review of this manuscript. The assistance of the following persons is also acknowledged: J. C. Turner, who performed many of the calculations; and J. W. Insalaco, W. C. Jordan, and R. I. Reynolds, who provided data for the calculations. J. T. Thomas and R. R. Rawl are acknowledged for recognizing the need for this work and developing the funding to support it. 


\begin{abstract}
Currently, $\mathrm{UF}_{6}$ cylinders designed to contain $2 \frac{1}{2}$ tons of $\mathrm{UF}_{6}$ are classified as Fissile Class II packages with a transport index (TI) of 5 for the purpose of transportation. The 10-ton $\mathrm{UF}_{6}$ cylinders are classified as Fissile Class I with no TI assigned for transportation. The 14-ton cylinders, although not certified for transport with enrichments greater than 1 wt \% because they have no approved overpack, can be used in on-site operations for enrichments greater than 1 wt $\%$. The maximum ${ }^{235} \mathrm{U}$ enrichments for these cylinders are $5.0 \mathrm{wt} \%$ for the $21 / 2$-ton cylinder and $4.5 \mathrm{wt} \%$ for the 10- and 14-ton cylinders. This work reviews the suitability for reclassification of the $21 / 2$-ton $\mathrm{UF}_{6}$ packages as Fissile Class I with a maximum ${ }^{235} \mathrm{U}$ enrichment of $5 \mathrm{wt} \%$. Additionally, the 10- and 14-ton cylinders are reviewed to address a change in maximum ${ }^{235} \mathrm{U}$ enrichment from 4.5 to $5 \mathrm{wt} \%$.

Based on this evaluation, the $2 \frac{1}{2}$-ton $\mathrm{UF}_{6}$ cylinders meet the $10 \mathrm{CFR} .71$ criteria for Fissile Class I packages, and no TI is needed for criticality safety purposes; however, a TI may be required based on radiation from the packages. Similarly, the 10- and 14-ton UF $_{6}$ packages appear acceptable for a maximum enrichment rating change to $5 \mathrm{wt} \%{ }^{235} \mathrm{U}$.
\end{abstract}




\section{INTRODUCTION}

The $21 / 2$-ton $\mathrm{UF}_{6}$ cylinder is currently in wide use for both national and international transport of $U \bar{F}_{6}$. Use across national boundaries necessitates licensing and certification activities within each country of transport. Recently, the Japanese attempted to arrange a shipment of $21 / 2$-ton $\mathrm{UF}_{6}$ cylinders with an assigned transport index (TI) of 0 . The U.S. Department of Transportation (DOT) currently assigns a TI of 5 to such shipments. Based on a rigorous Japanese supporting analysis and a known conservative approach of the U.S. analysis, the shipment was permitted. This criticality review is meant to provide a rigorous U.S. analysis to determine the TI for $21 / 2$-ton $U_{6}$ cylinder shipments.

The U.S. regulations governing the packaging and transportation of fissile radioactive materials are contained in the publication 10 CFR.71. ${ }^{1}$ Under the current 10 CFR.71 regulations, packages are classified according to Fissile Class I, II, or III and a corresponding TI is determined for each package design. Fissile Class I packages (TI not assigned, but effectively equal to zero) can be transported in unlimited numbers without any criticality safety controls. Fissile Class II packages $(0.1<\mathrm{TI} \leq 10)$ are normally limited to a cumulative TI (sum for all packages) of 50. A Fissile Class III shipment (packages with a $\mathrm{TI}>10$ ) requires special arrangements for control of each shipment. Under proposed rule changes, the fissile class designations are discontinued, while the $T I$ value ranges, $T I=0,0.1<T I \leq 10$, and $T I>10$, are still used to prescribe controls during shipment. The discussions in this report use both the old and the new package designations where possible, with greater emphasis on the Fissile Class designations since the proposed regulations are not in effect at the time the report is written.

This criticality safety review focuses on three $U_{6}$ packages currently in use: $21 \frac{1}{2}$-ton, 10 ton, and 14-ton $\mathrm{UF}_{6}$ cylinders. Because of the varied nature of each cylinder's use, they are treated separately.

The goal of the first phase of this work is to provide a review of the suitability of the $21 / 2$ ton cylinder and overpack for a subsequent reclassification as a Fissile Class $I(T I=0)$ package. Currently, the $2 \frac{1}{2}$-ton cylinder with the overpack is classified as a Fissile Class II $(\mathrm{TI}=5$ ) package $^{23}$ for the purpose of transportation. While the maximum ${ }^{235} \mathrm{U}$ enrichment that can be placed in this cylinder is $5.0 \mathrm{wt} \%$, shipments in excess of $1.0 \mathrm{wt} \%{ }^{235} \mathrm{U}$ require the cylinder be

\footnotetext{
"See Ref. 1 for definition of transport index.
} 
placed in an overpack. The overpack design for the $2 \frac{1}{2}$-ton cylinder has been granted approval from the U.S. Nuclear Regulatory Commission (NRC) [Certificate of Compliance (CoC) 4909 and $\mathrm{COC}$ 9196] and DOT (DOT 21-PI-1A and 21-PF-1B, referred to generically as the 21-PF-1). The technical results for the $2 \frac{1}{2}$-ton cylinder are presented in Sect. 3.

The second phase of this work assesses the impact on both the 10-ton and 14-ton cylinders of a change in maximum ${ }^{235} \mathrm{U}$ enrichment from $4.5 \mathrm{wt} \%$ to $5.0 \mathrm{wt} \%$. Specifically, for the 10-ton cylinder, the question to be addressed is what the new TI is for 5.0 wt \% product. For the 14-ton cylinder, the impact of such a change should only be felt for on-site operations and only an assurance of criticality safety is needed. In physical terms, the 10-ton ard 14-ton cylinders are very similar. Both cylinders have the same diameter, with the 14-ton cyling'er being longer than the 10-ton cylinder. They are both limited to a maximum of $4.5 \mathrm{wt} \%{ }^{235} \mathrm{U}$. However, only the 10-ton cylinder has an approved overpack; thus, the 14-ton cylinder cannot be shipped with greater than $1.0 \mathrm{wt} \%$ enrichment. The 14-ton cylinder is therefore used primarily for on-site operations rather than for transport. The 10-ton cylinder and overpack (the Paducah Tiger) are classified as a Fissile Class I $(\mathrm{TI}=0)$ package, ${ }^{4}$ having received approval for transport from the U.S. Department of Energy (DOE) (DOE 6553, currently under renewal) and the NRC (NRC 6553). The methods used in the analysis for both phases of this work are described in Sect. 2. The technical results for the 10- and 14-ton cylinders are described in Sect. 4.

The amount of internal moderation is very important for all three cylinders since a single cylinder is critical given sufficient moderation. Subcriticality is maintained through the use of moderation control, both by limiting the $\mathrm{H} / \mathrm{U}$ ratio to 0.088 and assuring the cylinder is a "leaktight" container. The justification of a "leak-tight" container is based on the physical and chemical characteristics of $\mathrm{UF}_{6}$ under transport conditions and the rigorous quality assurance used during package filling and preparation for transport. Therefore, a premise of no water inleakage into the $\mathrm{UF}_{6}$ cylinder is made for each of the above analyses. 


\section{ANALYSIS METHODOLOGY}

\subsection{ANALYSIS TOOLS}

The criticality calculations necessary for this review were performed using the CSAS25 control program of the SCALE-4 computer system. ${ }^{5}$ The functional modules executed by this program include BONAMI, NITAWL-II, and KENO V.a. The neutron cross sections used in this nroject were obtained from the SCALE 27-group ENDF/B-IV criticality library. Both the cross-section library and the SCALE-4 system are publicly available from the Radiation Shielding Information Center (RSIC). At Oak Ridge National Laboratory (ORNL), the SCALE-4 system is maintained under configuration control on an IBM mainframe. The SCALE 27-group library validation is discussed in the next section.

\subsection{VALIDATION STUDIES}

References 6-7 provide a basis for the validation of the analytic tools used for this project. The original validation effort applied to an early SCALE-3 version of the CSAS25/KENO V.a system on an IBM 3033 computer system. Reference 7 documents the updating of this validation effort for the SCALE-4 version of SCALE on the IBM mainframe at ORNL. Both validation efforts used the SCALE 27-group ENDF/B-IV cross-section library. This latest version was used to perform the calculations in this study.

The code and cross-section validation performed in ref. 7 consisted of determining $\mathbf{k}_{\text {eff }}$ for a series of 51 benchmark critical experiments. These benchmarks consisted of a full range of possible experiments including 11 highly enriched cases and 40 low-enriched cases. The resulting $\mathrm{k}_{\text {eff }}$ values were analyzed statistically to determine the single-sided, uniform width,

closed-interval, lower tolerance band ${ }^{8}$ such that $99.9 \%$ of the distribution of calculated $k_{\text {eff }}$ will fall above the tolerance band with a 95\% confidence level. The two curves shown in Fig. 1 give the least-squares fit and corresponding limit curve for the calculated $k_{\text {eff }}$ values of the 51 benchmark critical experiments as a function of the average neutron energy group causing fission, AEG. The top curve represents the least-squares fit to the data, and the bottom curve gives the lower limit of $\mathrm{k}_{\text {eff }}$ such that $99.9 \%$ of the distribution of calculated $\mathrm{k}_{\text {eff }}$ values are within the tolerance band with a confidence level of $95 \%$. This bottom curve, along with the range of AEG values for this problem, is used to establish the subcritical maximum $\mathrm{k}_{\text {eff }}$ value for this study. 


\section{K-eff vs. AEG Causing Fission \\ For 51 Benchmark Calculations}

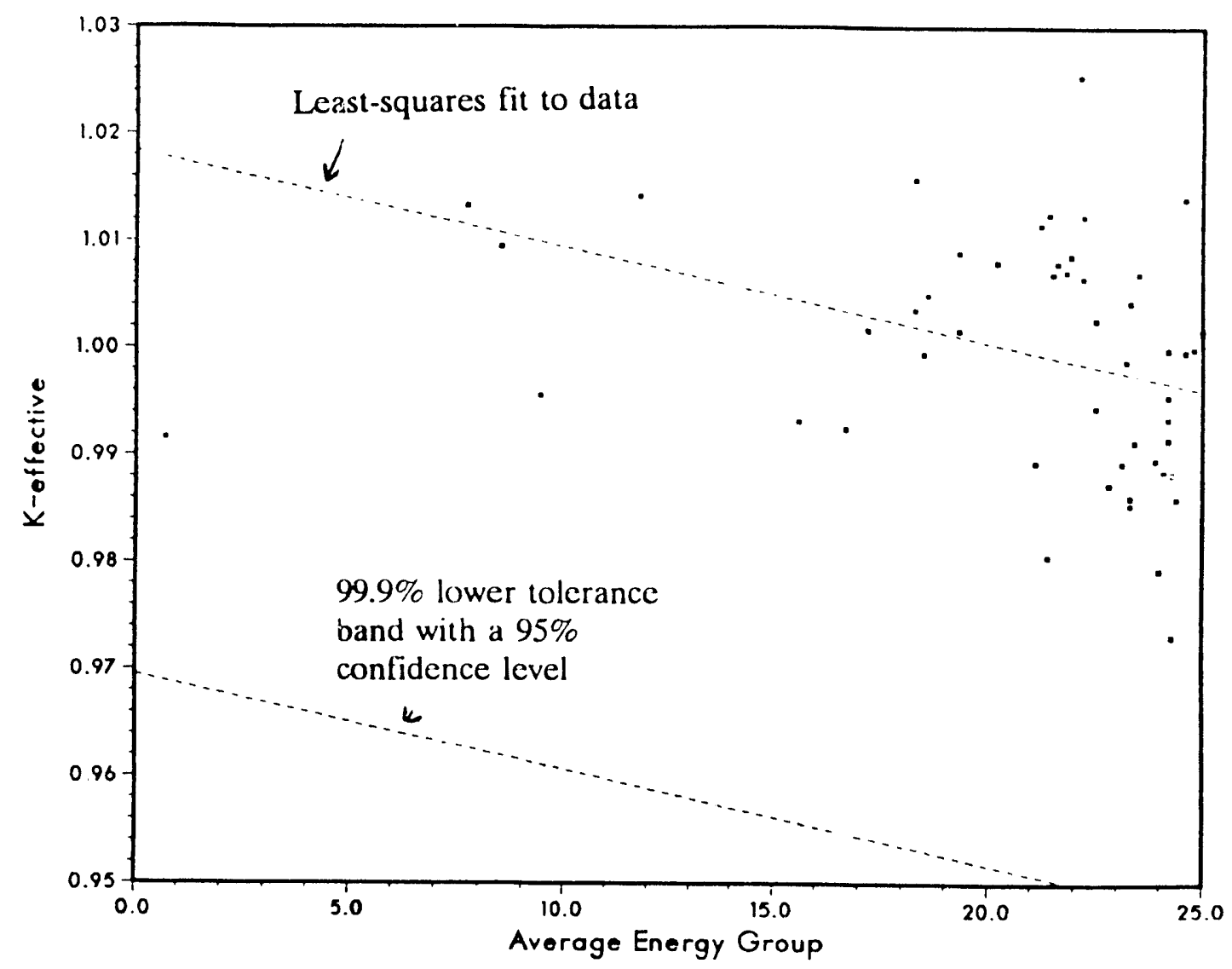

Fig. 1. $k_{\text {eff }}$ versus average energy group causing fission (AEG) for 51 benchmark calculations. 


\subsection{ANALYSIS OVERVIEW}

The Fissile Class I regulations in 10 CFR.71.57 require that subcriticality be assured during both normal and accident conditions. The regulations for normal conditions require that an infinite array of packages with optimum interspersed hydrogenous moderation be subcritical. The regulations for hypothetical accident conditions state that for 250 packages with optimal moderation between the packages, subcriticality must be assured. The analysis procedure described belcw should yield conservative estimates of $\mathbf{k}_{\text {eff }}$ for accident and normal conditions.

The procedure used in this study begins with an infinite array model of $2 \frac{1}{2}$ - and 10 -ton $\mathrm{UF}_{6}$ cylinders in their overpacks. The cylinder overpack is then replaced with variable-density vater. The pitch or spacing between the cylinders in the array is determined by the overpack size. This pitch is such that the packages, if the overpacks were present, would touch. The removal of the overpack increases $k_{\text {eff }}$ due to the removal of a neutron-absorbing interstitial material. The variable-density water region allows evaluation of a full range of moderation (from void to fuli-density water). In the absence of gross deformations in the geometry (see Refs. 2-4 for a discussion of protective packaging performance), the resulting curve of $\mathbf{k}_{\text {eff }}$ versus water density spans both the accident and normal conditions. The range of possible water densities is physically bounded on the low end by dry, burned insulation and on the high end by flooded conditions after a fire test where the insulation could possibly saturate with water. This range of possible water densities is bounded by the use of void to full-density values.

For the 14-ton cylinders, a similar approach was used in which the UF 6 cylinders were modeled with variable density interstitial water moderation. Cylinder-to-cylinder spacing was set at the same value as the 10-ton cylinder because both cylinders have the same diameter.

If the $k_{\text {eff }}$ values remain in the subcritical region for an infinite array with all possible water densities, then both accident and normal conditions of crit cality safety for Fissile Class I have been met. Additional array calculations with the overpack present can then he used to assess the change in $\mathbf{k}_{\mathrm{eff}}$ from the array results with no overpack. Calculations of single cylinders without overpacks and with infinite water reflection are used to provide calculational checks on some of the array results.

The arrays as described above were all modeled as square lattices. The use of a triangular pitch allows for a denser packing; however, the geometry is much more difficult to model in the computer code. A triangular pitch array is possible only for the $21 / 2$ - and 14 -ton cylinders, since the 10-ton cylinder has a square overpack. However, pitch reduction cases were 
evaluated for all three cylinders to verify the expected lack of sensitivity to cylinder-to-cylinder spacings. Portions of the $k_{\text {eff }}$ versus water density curve corresponding to near-peak conditions were regenerated for all three cylinder sizes assuming a 7\% reduction in the cylinder-to-cylinder spacings (i.e., pitch). The $7 \%$ pitch reduction accounts for the difference in packing factors for the two lattices $(0.79$ for square pitch versus 0.90 for triangular pitch) because the cell volume varies as the square of the pitch. For these additional runs, the peak value of $k_{\text {eff }}$ is not expected to differ from the previous runs. However, due to the differing interstitial volumes, the water density at peak $\mathrm{k}_{\text {eff }}$ is expected to shift somewhat.

\subsection{SENSITIVITY STUDIES}

The final set of calculations investigates temperature and fuel location effects. The temperature effects investigate the reactivity consequences of high $\mathrm{UF}_{6}$ temperatures (corresponding to the fire test conditions) and low $\mathrm{UF}_{6}$ temperatures $\left(-40^{\circ} \mathrm{C}\right.$ as required in 10 CFR.71.55 part d). The fuel location studies are necessary because the actual $\mathrm{UF}_{6}$ configuration in each cylinder may vary. Thus, the most reactive fuel configuration must be determined. The configurations studied are shown in Fig. 2. The models are not drawn to scale, but simply to indicate the gross fuel location patterns. Models (a)-(c) each have approximately $40 \%$ void space. The fuel density for model (d) is reduced, such that all models have the same $\mathrm{UF}_{6}$ loading. Model (c) represents the configuration due to the filling of a cylinder with liquid $\mathrm{UF}_{6}$, which then cools uniformly from the outside with a corresponding decrease in volume. The resulting solid $\mathrm{UF}_{6}$ typically has a void in the center. Model (a) represents the opposite configuration from model (c), and model (b) represents the fuel configuration expected from preferential cooling of $\mathrm{UF}_{6}$ on only one side of the $\mathrm{UF}_{6}$ cylinder. Model (d) approximates the low-density $\mathrm{UF}_{6}$ fuel configuration. Experiments ${ }^{9}$ have shown the most likely configuration to be a combination of model (b) and model (c), with the central void in model (c) shifted toward the cylinder edge slightly. Base case calculations were performed with model (c).

Additional calculations will investigate the reactivity effects of varying the $\mathrm{UF}_{6}$ and moderator temperature during accident conditions. Temperature effects can be broken into density variations (both $\mathrm{UF}_{6}$ and moderator) and resonance-capture variations. The density variations are accounted for in the fuel locations studies [e.g., model (d) above for low density $\mathrm{UF}_{6}$ ] and the variable-water density calculations to obtain the optimal interstitial moderation. The resonance capture effects will be studied by performing three calcuiations, one at normal 


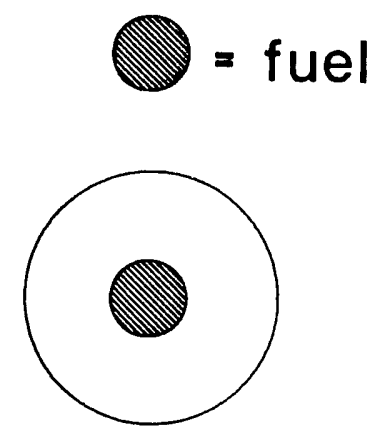

(a)

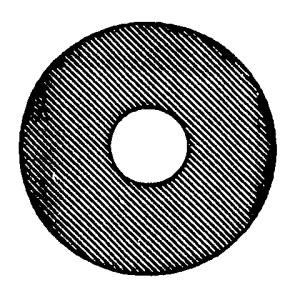

(c)

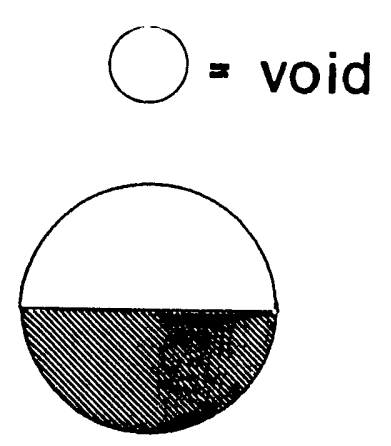

(b)

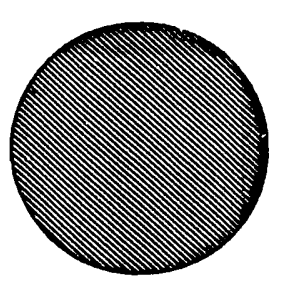

(d)

Fig. 2. Fuel locations analyzed to determine most reactive configurations for a constant mass. temperature, one at elevated temperatures corresponding to an accident case, and one at $-40^{\circ} \mathrm{C}$ as required in $10 \mathrm{CFR} .71 .55(\mathrm{~d})$. A standard temperature of $20^{\circ} \mathrm{C}$ was used for the base case.

\section{2⿺辶2-TON CYLINDER ANALYSIS}

Phase I of the analysis evaluated the $21 / 2$-ton cylinder and its corresponding overpack, DOT 21PF-1, following closely the general description given in Sect. 2. This included the use of moderation control and the use of a "leak-tight" container to limit the hydrogenous material within the cylinder. The fuel region model was based on the fuel configuration shown in Fig. 2(c). An infinite array model incorporating an internal $H / U$ ratio of 0.088 was then developed to allow the determination of the optimal interstitial moderation. In the $2 \frac{1 / 2}{2}$-ton cylinder model, the overpack is removed and replaced with variable-density water, while maintaining the same package-to-package spacing as a square-pitch array with the overpacks touching. The neglect of the overpack makes the results conservative (i.e., increases $k_{\text {eff }}$ ) 
because of the removal of neutron-absorbing materials. The variable-density water region allows for the determination of optimal interstitial moderation.

\subsection{MODEL DESCRIPTION}

The $21 \frac{1}{2}$-ton $U_{6}$ cylinder model was developed from the actual cylinder and overpack dimensions contained in ref. 10. The steel cylinder radius was taken directly from the description in ref. 10. The curved lid and bottom surfaces of the cylinder were not modeled exactly; instead, the internal height of the cylinder cavity was determined from the volume as reported in ref. 10 . The resulting model has a flat head and bottom rather than the actual curved one. The volume of the $\mathrm{UF}_{6}$ inside the cylinder was obtained from the total $\mathrm{UF}_{6}$ weight and a $\mathrm{UF}_{6}$ density of 5.1 $\mathrm{g} / \mathrm{cm}^{3}$, as given in ref. 10. The inner radius of $U_{6}$ [see model (c) in Fig. 2] was then determined from the resulting volumes assuming a uniform $\mathrm{UF}_{6}$ thickness on the sides and ends of the cylinder. The single cylinder model is shown in Fig. 3 and was reflected on each of the six faces for infinite array criculations. Also, the single unit calculations used this model with the variablewater density region replaced with an effectively infinite water reflector. Similarly, the calculation with a $7 \%$ reduction in the pitch (approximating a triangular pitch array) used the same model except the outermost dimension (i.e., the outer boundary of the variable-water density region) was reduced by $7 \%$. The cylinder was assumed to be centered axially within the variable-water density region.

The model described above and shown in Fig. 3 is approximate due to the replacement of the overpack by variable-density water. The model shown in Fig. 4 corresponds to the $21 / 2$-ton cylinder in an overpack (DOT 21-PF-1). Calculations performed with this model can be directly compared with those using variable water density at a water density which is equivalent to the hydrogenous content of the overpack. This comparison allows the change in $k_{\text {eff }}$ for the model shown in Fig. 3 to be determined.

The materials contained in each region specified in Figs. 3-4 are described in detail in Tables 1 and 2. Table 1 presents each material, its total mass in the model, and its actual mass. Table 2 gives the material constituents and their respective atomic densities for completeness.

The models described above give the details for only one unit (i.e., a complete cylinder with and without its overpack). For infinite array calculations, these models were reflected on each of the six faces to represent an infinite array. No finite arrays were included in this study. 


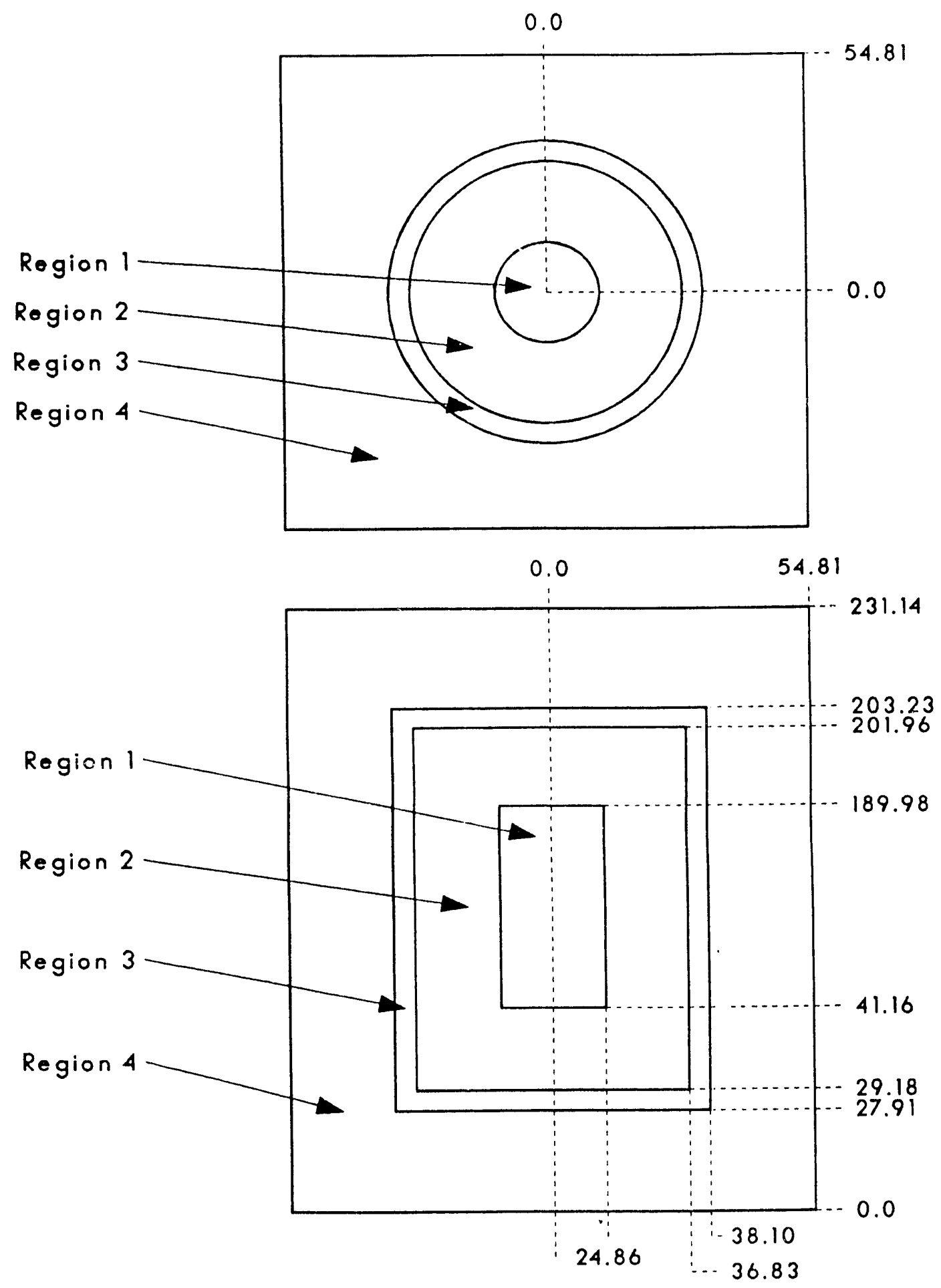

Fig. 3. Model for $2 \frac{1}{2}$-ton cylinder without overpack. (All dimensions in $\mathrm{cm}$.) 


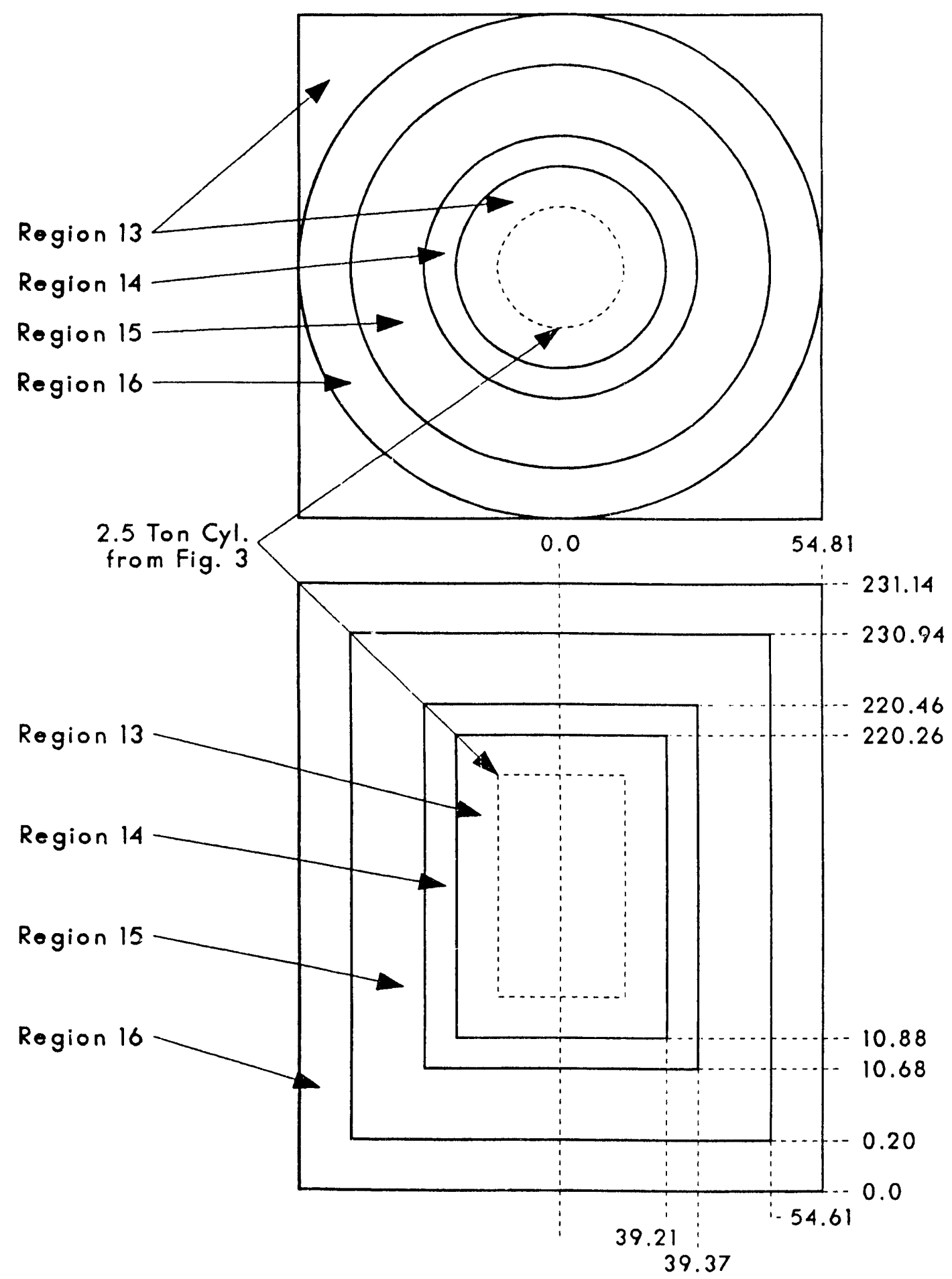

Fig. 4. Model for DOT 21-PF-1 overpack. (All dimensions in $\mathrm{cm}$.) 
Table 1 . Constituent material mass and density (21/2-ton cylinders)

\begin{tabular}{|c|c|c|c|c|c|}
\hline Region & $\begin{array}{c}\text { Shown in } \\
\text { Fig. }\end{array}$ & Material & Density & $\begin{array}{c}\text { Model mass } \\
(\mathrm{kg})\end{array}$ & $\begin{array}{c}\text { Actual mass } \\
(\mathrm{kg})\end{array}$ \\
\hline \multicolumn{6}{|c|}{$21 / 2-$ ton cylinder } \\
\hline 1 & 3 & Void & - & - & - \\
\hline 2 & 3 & $\mathrm{UF}_{6}$ & 5.1 & 2,281 & 2,277 \\
\hline 3 & 3 & Steel & 7.8212 & 495 & 635 \\
\hline 4 & 3 & Water or void & Variable & Variable & - \\
\hline \multicolumn{6}{|c|}{ DOT 21-PF1 } \\
\hline 13 & 4 & Void & - & - & - \\
\hline 14 & 4 & Steel & 7.8212 & 80 & NA \\
\hline 15 & 4 & Phenolic foam & 0.029 & 33 & NA \\
\hline 16 & 4 & Steel & 7.8212 & 154 & NA \\
\hline
\end{tabular}

Table 2. Constituent material number density data (21/2-ton cylinders)

\begin{tabular}{|c|c|c|c|c|}
\hline Region & Material/Reference & $\begin{array}{l}\text { Density } \\
(\mathrm{g} / \mathrm{cc})\end{array}$ & Constituent & $\begin{array}{l}\text { Atom density } \\
\text { (atoms } / \mathrm{b}-\mathrm{cm})\end{array}$ \\
\hline 2 & $\mathrm{UF}_{6} /$ ref. 10 & 5.1 & $\begin{array}{r}{ }^{235} \mathrm{U} \\
\mathrm{F} \\
\mathrm{H}\end{array}$ & $\begin{array}{l}4.4168 \mathrm{E}-4 \\
8.2860 \mathrm{E}-3 \\
5.3134 \mathrm{E}-2 \\
7.6800 \mathrm{E}-4\end{array}$ \\
\hline $3,14,16$ & $\begin{array}{l}\text { Carbon steel/ref. } 5 \\
\text { SCALE standard } \\
\text { composition }\end{array}$ & 7.8212 & $\begin{array}{l}\mathrm{Fe} \\
\mathrm{C}\end{array}$ & $\begin{array}{l}8.3498 \mathrm{E}-2 \\
3.9250 \mathrm{E}-3\end{array}$ \\
\hline 4 & $\begin{array}{l}\text { Variable-density water/ } \\
\text { ref. } 5 \\
\text { SCALE standard } \\
\text { composition }\end{array}$ & $0.9982^{*}$ & $\begin{array}{l}\mathrm{H} \\
\mathrm{O}\end{array}$ & $\begin{array}{l}6.6751 \mathrm{E}-2^{*} \\
3.3376 \mathrm{E}-2^{*}\end{array}$ \\
\hline 15 & $\begin{array}{l}\text { Phenolic foam/ } \\
\text { ref. } 11\end{array}$ & 0.029 & $\begin{array}{c}\mathrm{C} \\
\mathrm{H} \\
{ }^{10} \mathrm{~B} \\
{ }^{11} \mathrm{~B} \\
\mathrm{Si} \\
\mathrm{Cl} \\
\mathrm{O}\end{array}$ & $\begin{array}{l}5.9669 \mathrm{E}-4 \\
7.7981 \mathrm{E}-4 \\
1.0221 \mathrm{E}-5 \\
4.1465 \mathrm{E}-5 \\
1.3680 \mathrm{E}-5 \\
2.4630 \mathrm{E}-6 \\
5.3063 \mathrm{E}-4\end{array}$ \\
\hline
\end{tabular}

*Corresponds to full-density water. 


\subsection{ANALYSIS RESULTS FOR 21/2-TON CYLINDER}

Calculational results are given below for

1. infinite arrays with variable-density water replacing the overpacks (3.2.1),

2. an infinite array with the DOT 21-PF-1 overpack modeled (3.2.2),

3. a single $2 \frac{1}{2}$-ton cylinder surrounded by an effectively infinite water reflector (3.2.3), and

4. fuel location and temperature sensitivity calculations (3.2.4).

These latter calculations allow the quantification of reactivity effects of fuel configuration inside the $\mathrm{UF}_{6}$ cylinder and the effects of low and high fuel temperatures corresponding to accident conditions. An overview of these calculations and their purposes are given in Table 3.

Table 3. Different types of calculations and their use in this study

\begin{tabular}{|c|c|}
\hline Calculation type & Purpose \\
\hline \multicolumn{2}{|l|}{$\begin{array}{l}\text { Infinite array with variable } \\
\text { interstitial water density } \\
\text { (without overpack) }\end{array}$} \\
\hline Original outer radius & Seek optimal interstitial moderation \\
\hline $7 \%$ reduced outer radius & $\begin{array}{l}\text { Verify optimal conditions at different } \\
\text { radius, estimate square-pitch versus } \\
\text { triangular-pitch effects }\end{array}$ \\
\hline Infinite arrays with overpacks modeled & Estimate change in $k_{\text {eff }}$ due to neglecting overpack \\
\hline Single unit, infinite water reflection & $\begin{array}{l}\text { Meet regulatory requirement, consistency check } \\
\text { on full-density water values from infinite array } \\
\text { calculations }\end{array}$ \\
\hline $\begin{array}{l}\text { Temperature effects at near } \\
\text { optimal conditions }\end{array}$ & $\begin{array}{l}\text { Estimate iemperature effects for accident } \\
\text { conditions }\end{array}$ \\
\hline Fuel configuration (see Fig. 2) & Identify most reactive fuel configurations \\
\hline
\end{tabular}

\subsubsection{Infinite Array Results without Overpacks}

A plot of the $k_{\text {eff }}$ versus interstitial water specific gravity (SG) for the $2 \frac{1}{2}$-ton $U_{6}$ cylinder is shown in Fig. 5. The $k_{\text {eff }}$ values are plotted versus water SG for convenience; however, the corresponding water density at a SG of 1.0 is $0.9982 \mathrm{gm} / \mathrm{cm}^{3}$ (water at $20^{\circ} \mathrm{C}$, standard pressure). Thus, the abcissa label could be replaced with "water density." General 
features of the curve include a peaking of $k_{\text {eff }}$ for low water $S G$, followed by a steep decrease with increasing water SG, and ending with a slight increase near unity SG. The peak $k_{\text {eff }}$ value of $0.817 \pm 0.003$ at an SG of 0.015 represents the point of optimum interstitial moderation. The rapid decrease in $\mathrm{k}_{\text {eff }}$ results for larger water $\mathrm{SG}$ indicates an overmoderated condition. The slight increase in $k_{\text {eff }}$ at $S G$ values near unity arise from a change in role of the water from a moderating material to a reflecting material.

Details of the region around the peak $\mathrm{k}_{\text {eff }}$ values are shcwn in Fig. 6. Here, the original curve for square lattice pitch is shown along with the curve for the $7 \%$ reduced pitch (associated with triangular pitch). The original curve peaks at a slightly lower SG value $(0.015)$ than the $7 \%$ reduced pitch case (0.020). However, the corresponding peak values of $0.817 \pm 0.003$ and $0.816 \pm 0.002$ are statistically indistinguishable. This is the expected behavior since the interaction between neighboring packages is governed by the total mass of moderating material. For differing separation distances, but equal masses, the densities (SG) should change while the $\mathrm{k}_{\text {eff }}$ values remain constant. The $\mathrm{k}_{\text {eff }}$ value of 0.817 should therefore represent a maximum for the $2 \frac{1}{2}$-ton cylinder for up to $2,277 \mathrm{~kg}$ of $\mathrm{UF}_{6}$ at $5 \mathrm{wt} \%$.

\subsubsection{Infinite Array Results with Overpacks}

The previous infinite array calculations were all performed with models that replaced the overpacks with variable-density water. Additional calculations were then performed for the $21 / 2$ ton cylinder with its overpack to assess the degree of conservatism in the preceding results. These calculations, as before, were for an infinite array of these units. The $k_{\text {eff }}$ value for the $2 \frac{1}{2}$-ton cylinder is $0.655 \pm 0.002$. The effective water SG for this case is 0.01 . Comparing these $k_{\text {eff }}$ values with the values from Fig. 5 indicates that the cylinder overpack decreases $k_{\text {eff }}$ by $0.15 \Delta \mathrm{k}$ for the $2 \frac{1}{2}$-ton cylinder.

\subsubsection{Single Unit Results}

The single unit model for the $21 / 2$-ton cylinder consisted of the cylinder without an overpack with an effectively infinite water reflector. This case should be essentially identical to the infinite array $k_{\text {eff }}$ value with full-density water $(S G=1)$ because the water acts as an infinite reflector at full density. The single unit result is $0.453 \pm 0.003$. This result is nearly identical with the $S G=1.0$ value shown in Fig. 5. The single unit result is primarily used as an independent consistency check on the infinite array results. 


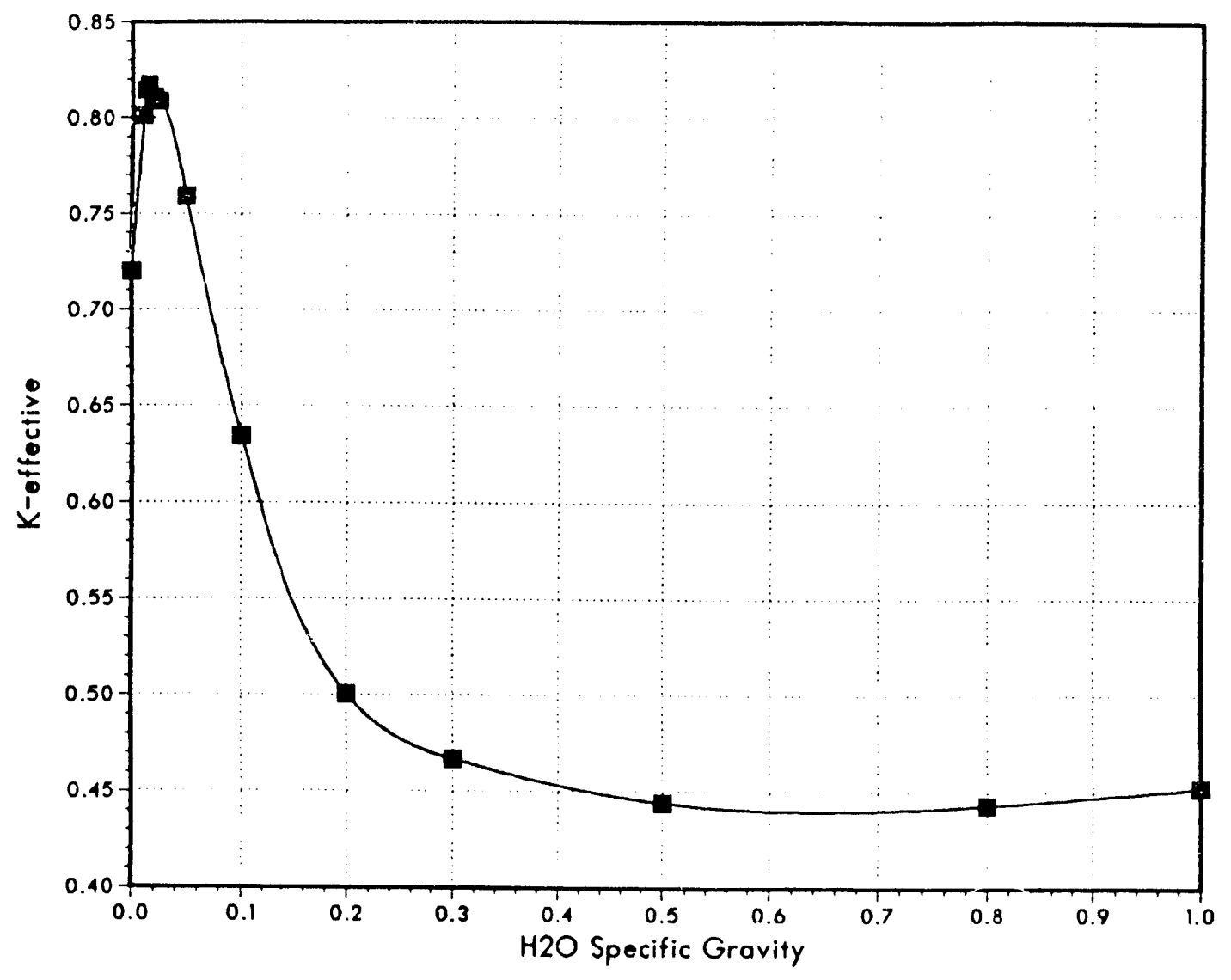

Fig. 5. Plot of $k_{\text {eff }}$ versus water specific gravity for infinite array of $21 / 2$-ton $U_{6}$ cylinders (square-lattice, full-diameter model). 


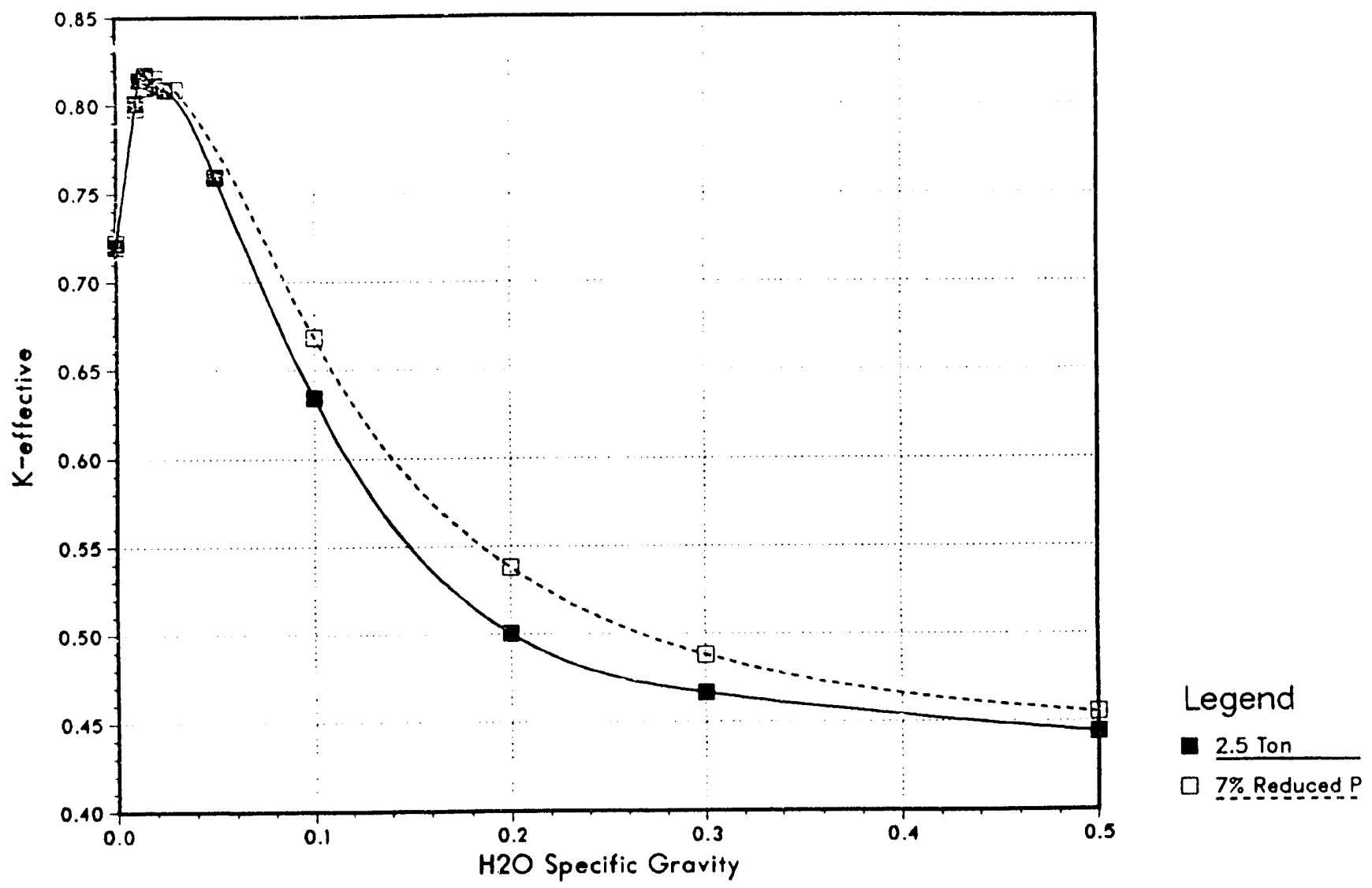

Fig. 6. Plot of $k_{e f}$ versus water specific gravity for infinite array of $2 \frac{1 / 2-t o n}{U_{F}} F_{6}$ cylinders for original and $7 \%$ reduced pitch case. 


\subsubsection{Sensitivity Results}

The temperature for all calculations thus far has been $20^{\circ} \mathrm{C}$. The final set of calculations quantified the effects of temperature and fuel location on the $k_{\text {eff }}$ results. The temperature effects were estimated by analyzing the $2 \frac{1}{2} 2$-ton cylinder at optimal moderation (an SG of 0.0150 ) with temperatures of $65^{\circ} \mathrm{C}, 20^{\circ} \mathrm{C}$, and $-40^{\circ} \mathrm{C}$. The $\mathrm{k}_{\text {eff }}$ values for $65^{\circ} \mathrm{C}$ and $-40^{\circ} \mathrm{C}$ are $0.817 \pm 0.002$ and $0.818 \pm 0.003$, respectively. These values are equivalent to the base $k_{\text {eff }}$ at $20^{\circ} \mathrm{C}$ of $0.817 \pm 0.003$. The temperature effects are thus extremely minimal.

The second sensitivity area investigated was that of fuel configuration. The infinite array model used for this study was the $21 / 2$-ton cylinder at a water SG of 0.02 (see Fig. 5). The fuel location studies analyzed all the cases shown in Fig. 2. Case (c) is the fuel geometry chosen for all cases thus far. This geometry was chosen since it was a likely physical configuration and also was expected to be the most reactive. The array results for cases $a, b, c$, and $d$ are $0.774 \pm$ $0.002,0.782 \pm 0.003,0.811 \pm 0.003$, and $0.812 \pm 0.003$, respectively. Cases (c) and (d) are statistically indistinguishable when the standard deviations are taken into account and represent maximum reactivity conditions.

\subsubsection{Validation Results}

The complete set of supporting results for the plots shown in Figs. 5-6 are given in Table 4. In addition to the $k_{\text {eff }}$ and water SG values, the table reports the AEG parameter values used for correlation to the lower limit of $\mathbf{k}_{\text {eff }}$ as discussed previously in Sect. 2.3. The values of AEG given in the table range from 9 to 16 . Over this range, in Fig. 1 the lower tolerance limit (subcritical limit) falls between 0.953 and 0.961 . For conservatism and convenience, the single value of 0.95 is chosen as the upper subcritical limit of $\mathbf{k}_{\text {eff }}$ for this study. Thus, the acceptance criteria for the calculational results presented above are the reported $k_{\text {eff }}$ plus two standard deviations must be less than 0.95 , and the AEG is within the range of 9 to 16 .

\subsection{Summary}

The maximum $k_{\text {eff }}$ value for the conditions of optimal interstitial moderation with the premise of no water leakage into the $\mathrm{UF}_{6}$ cylinder, has been shown to be $0.817 \pm 0.003$ for the $21 / 2$-ton cylinder with $5 \mathrm{wt} \%{ }^{235} \mathrm{U}$ enrichment. Applying a $2 \sigma$ safety margin yields a $\mathrm{k}_{\text {eff }}$ value of 0.823 . Since this is a peak value, the $2 \frac{1}{2} 2$-ton cylinder has a $k_{\text {eff }}$ less than the 0.95 upper subcritical limit criterion at all interstitial moderation conditions. These $k_{\text {eff }}$ values have been 
Table 4. Tabulated results for various models of $2 \frac{1}{2}-$ ton cylinders

\begin{tabular}{|c|c|c|c|c|}
\hline Case & $k_{\text {df }}$ & Std. dev. & Water SGe & $\mathrm{AEG}^{b}$ \\
\hline \multicolumn{5}{|c|}{ Infinitc array-square lattice pitch } \\
\hline \multicolumn{5}{|l|}{$21 / 2$-ton results } \\
\hline UF1 & 0.452 & 0.003 & 1.0 & 14.4 \\
\hline UF 15 & 0.443 & 0.003 & 0.8 & 14.4 \\
\hline UF3 & 0.444 & 0.003 & 0.5 & 14.3 \\
\hline UF14 & 0.467 & 0.003 & 0.3 & 14.9 \\
\hline UF13 & 0.500 & 0.003 & 0.2 & 15.4 \\
\hline UF4 & 0.634 & 0.003 & 0.1 & 16.7 \\
\hline UF5 & 0.759 & 0.003 & 0.05 & 16.6 \\
\hline UF6 & 0.809 & 0.003 & 0.025 & 15.4 \\
\hline UF8 & 0.811 & 0.003 & 0.02 & 14.8 \\
\hline UFG & 0.817 & 0.003 & 0.015 & 14.1 \\
\hline UF10 & 0.814 & 0.002 & 0.012 & 13.5 \\
\hline UF7 & 0.801 & 0.002 & 0.01 & 13.0 \\
\hline UF2 & 0.720 & 0.002 & 0.0 & 9.3 \\
\hline \multicolumn{5}{|c|}{ Infinite array-7\% reduced pitch } \\
\hline \multicolumn{5}{|l|}{$21 / 2-\operatorname{ton}$ results } \\
\hline UF20 & 0.455 & 0.003 & 0.5 & 14.5 \\
\hline UF22 & 0.488 & 0.002 & 0.3 & 15.1 \\
\hline UF21 & 0.538 & 0.003 & 0.2 & 15.8 \\
\hline UF19 & 0.668 & 0.003 & 0.1 & 16.7 \\
\hline UF18 & 0.809 & 0.003 & 0.03 & 15.3 \\
\hline UF17 & 0.816 & 0.002 & 0.02 & 14.3 \\
\hline UF16 & 0.810 & 0.002 & 0.015 & 13.5 \\
\hline \multicolumn{5}{|c|}{ Overpact array results } \\
\hline $\begin{array}{l}21 / 2 \text {-ton result } \\
\text { UFO1 }\end{array}$ & 0.655 & 0.002 & 0.01 & 10.3 \\
\hline \multicolumn{5}{|c|}{ Single unit-infinite $\mathrm{H}_{2} \mathrm{O}$ reflection } \\
\hline $21 / 2$-ton result & & & & \\
\hline UF59 & 0.453 & 0.003 & 1.0 & 14.4 \\
\hline \multicolumn{5}{|c|}{ Temperature effocts } \\
\hline \multicolumn{5}{|l|}{$21 / 2$-ton results } \\
\hline UFT1 $\left(65^{\circ} \mathrm{C}\right)$ & 0.817 & 0.002 & 0.015 & 14.1 \\
\hline UF9 $\left(20^{\circ} \mathrm{C}\right)$ & 0.817 & 0.003 & 0.015 & 14.1 \\
\hline UFT3 $\left(-40^{\circ} \mathrm{C}\right)$ & 0.818 & 0.003 & 0.015 & 14.0 \\
\hline \multicolumn{5}{|c|}{ Fuel location effocts } \\
\hline \multicolumn{5}{|l|}{$21 / 2$-ton results } \\
\hline UFAl (Fig. 2a) & 0.774 & 0.002 & 0.020 & 14.2 \\
\hline UFB1 (Fig. 2b) & 0.782 & 0.003 & 0.020 & 14.3 \\
\hline UF8 (Fig. 2c) & 0.811 & 0.003 & 0.020 & 14.8 \\
\hline UFF1 (Fig. 2d) & 0.812 & 0.003 & 0.020 & 14.8 \\
\hline
\end{tabular}

-Specific gravity.

${ }^{b}$ Average energy group causing fission. 
shown to be insensitive to cylinder spacing and temperature effects. This final $k_{\text {eff }}$ value corresponds to an infinite array of optimal interstitially moderated cylinders; thus both normal and accident conditions for Fissile Class I have been met. These final calculations should be conservative due to the neglect of the overpack materials. The degree of conservatism in $\mathrm{k}_{\text {eff }}$ has been estimated at $20 \%$ for the $2 \frac{1}{2}$-ton cylinder.

Based on this evaluation, the $2 \frac{1}{2}$-ton $\mathrm{UF}_{6}$ cylinder sith $5 \mathrm{wt} \%{ }^{235} \mathrm{U}$ enrichment meets the 10 CFR.71 criteria for Fissile Class I packages, and has a TI of zero for criticality safety purposes.

\section{10- AND 14-TON CYLINDER ANALYSIS}

Phase II of the analysis evaluated the 10- and 14-ton UF $_{6}$ cylinders in a very similar fashion to the $2 \frac{1}{2}$-ton analysis described in Sect. 3. The use of moderation control (with $\mathrm{H} / \mathrm{U}$ of 0.088 ) and the assumption of a "leak-tight" container were again employed in the analysis of the 10- and 14-ton cylinders. The fuel region model was again based on the fuel configuration shown in Fig. 2(c). Infinite array models of the $\mathrm{UF}_{6}$ cylinders with variable-density water interspersed were used to determine the optimal interstitial moderation. These infinite array models were analyzed with cylinder spacing corresponding to a square-lattice arrangement followed by a reduced-pitch square lattice to approximate a triangular pitch lattice arrangement.

\subsection{MODEL DESCRIPTION}

The calculational models of the 10- and 14-ton $\mathrm{UF}_{6}$ cylinders (Figs. 7-8) were based on the physical descriptions given in ref. 10. Approximations were made in these models primarily in the head and buttom regions. These regions were modeled as flat, where the actual geometry was curved. The cylinder internal volume was conserved, while the amount of steel in the cylinder wall was underestimated for conservatism (steel is an absorber, the removal of which should increase $k_{\text {eff }}$ ). The $\mathrm{UF}_{6}$ was assumed to adhere to the cylinder walls with a central void space as shown approximately in Fig. 2(c). For both the 10- and 14-ton cylinders, the void space was approximately $40 \%$.

Calculations were performed for the models shown in Figs. 7-8 in three different ways. Single packages were analyzed with the models shown in Figs. 7-8 surrounded by an effectively 
infinite water reflector. Infinite ar calculations were also performed by specifying reflective or mi-ror-type boundary conditions for each face of the single package models. The final type of calculation consisted of placing the single $\mathrm{UF}_{6}$ cylinder models inside the 10-ton overpack (Paducah Tiger overpack) shown in Fig. 9. This calculation allows determination of the increase in $k_{\text {eff }}$ when the overpack is removed.

The materials specifications for each region shown in Figs. 7-9 are described in detail in Tables 5-6. The materials number density, actual mass, and mass in the model are given for completeness.

\subsection{ANALYSIS RESULTS FOR 10- AND 14TON CYLINDERS}

Calculational results are given below for

1. infinite arrays of these cylinders with variable-density water replacing the overpack (4.2.1),

2. an infinite array of the Paducah Tiger overpacks containing 10-ton $\mathrm{UF}_{6}$ cylinders (4.2.2), and

3. single 10- and 14-ton $\mathrm{UF}_{6}$ cylinders surrounded by an effectively infinite water reflector (4.2.3).

The infinite array calculations with variable-density water constitute the major portion of the analysis. These calculations allow the optimal interstitial moderation and, hence, peak $k_{\text {eff }}$ value to be determined. The single package results are essentially a check on the array calculations since the array calculations for full-density interstitial water, and those for the single package with an effectively infinite moderator thickness, should be virtually identical. The calculations with the overpack modeled (only for 10-ton cylinder; allows the conservatism in the approximate model to be evaluated.

\subsubsection{Infinite Array Results without Overpacks}

Plots of $k_{\text {eff }}$ versus interstitial SG for both the 10- and 14-ton cylinders are shown in Figs. 10-13. These $k_{\text {eff }}$ values are plotted versus water SG for convenience; however, the corresponding water density at an SG of 1.0 is $0.9982 \mathrm{gm} / \mathrm{cm}^{3}\left(20^{\circ} \mathrm{C}\right.$, standard pressure). Thus, the abcissa label could be replaced with "water density." The same general trends seen for the $21 / 2$-ton cylinder are seen for the 10- and 14-ton cylinders. Generally, the curves peak for low water SG, followed by a steep decrease with increasing water SG, ending with a slight increase 


\section{NOT TO SCALE}

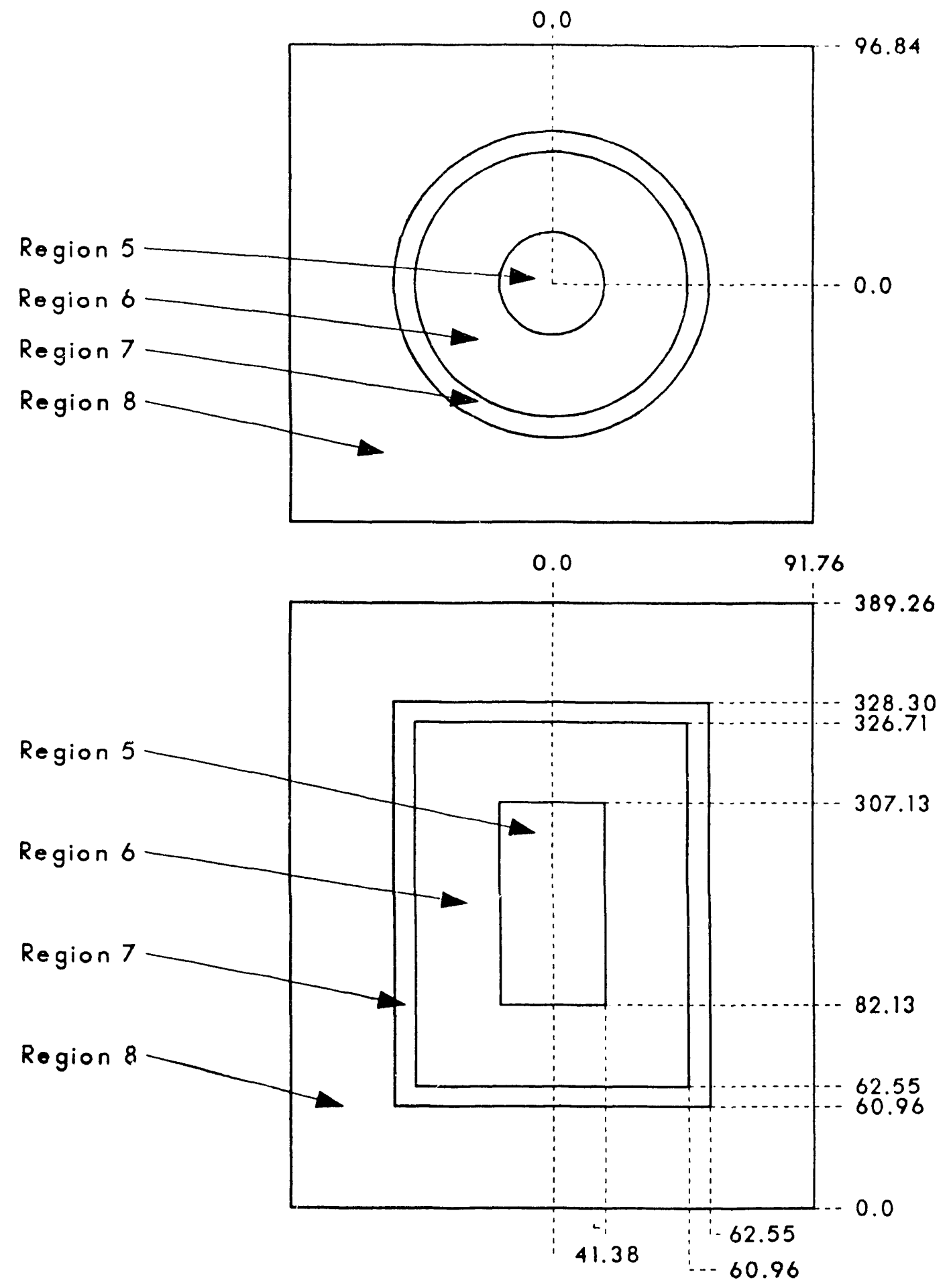

Fig. 7. Model for 10-ton cylinder without overpack. (All dimensions in $\mathrm{cm}$.) 


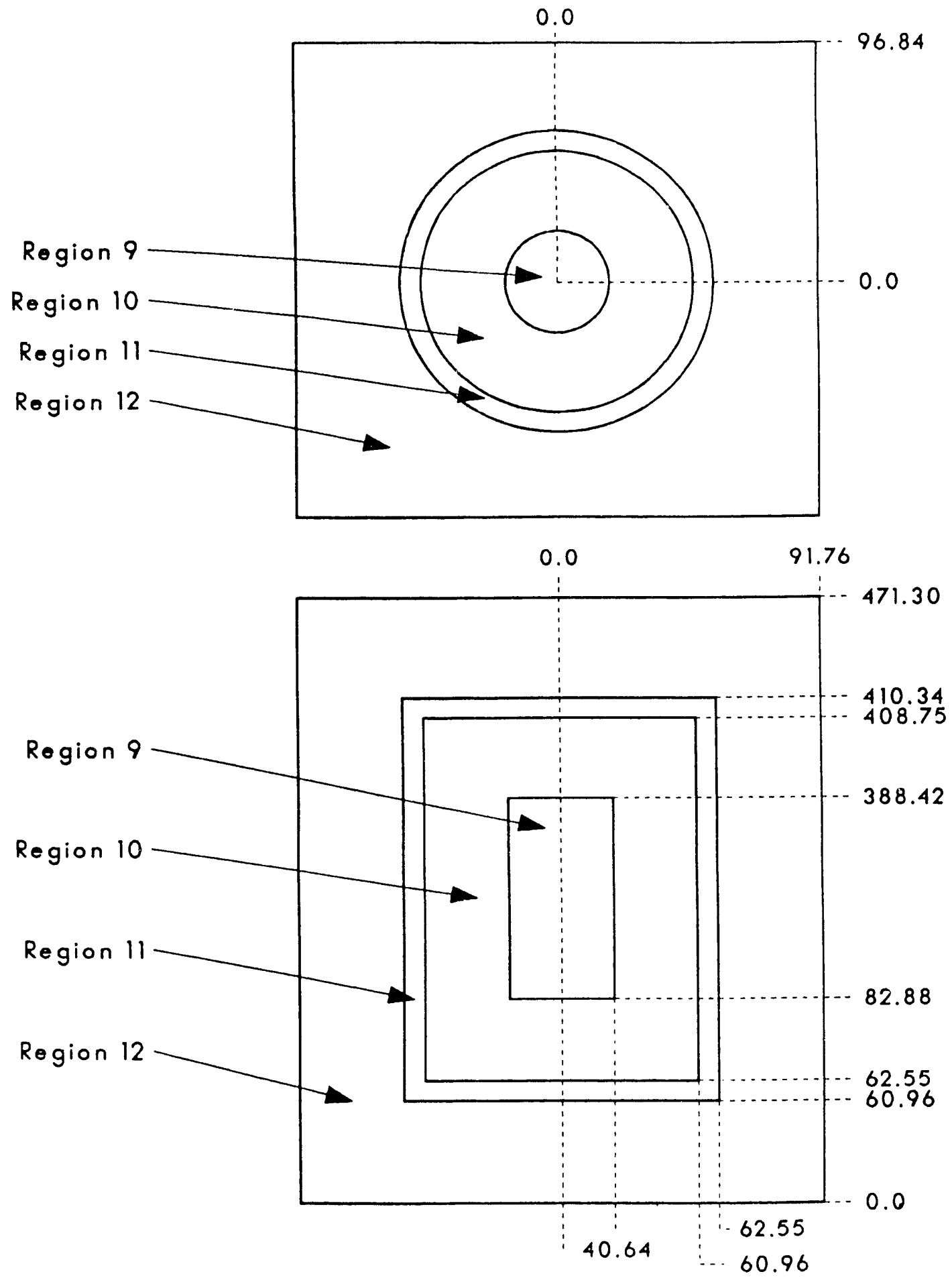

Fig. 8. Model for 14-ton cylinder without overpack. (All dimensions in $\mathrm{cm}$.) 


\section{NOT TO SCALE}

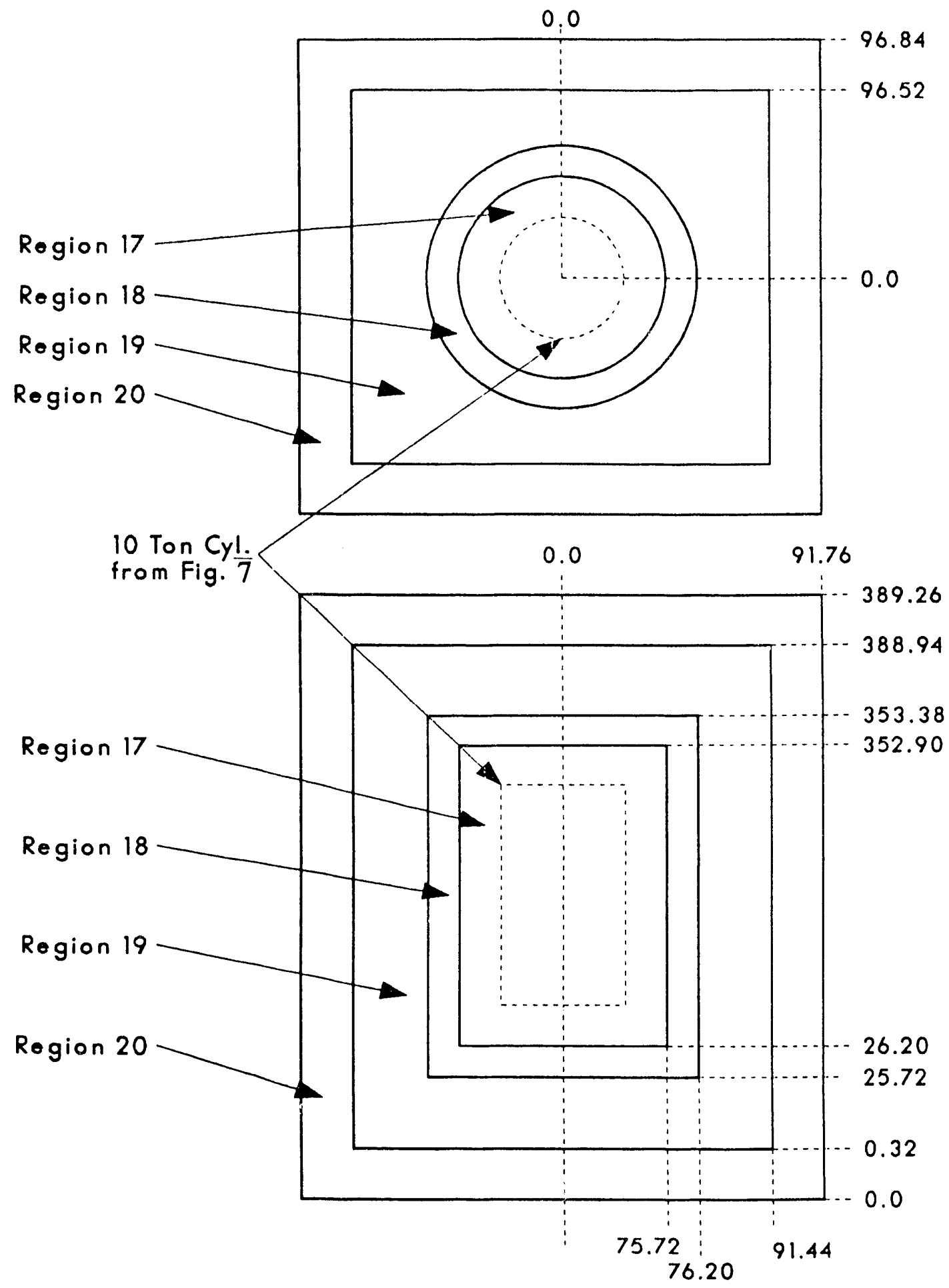

Fig. 9. Model for Paducah Tiger overpack. (All dimensions in $\mathrm{cm}$.) 
Table 5. Constituent material mass and density (10- and 14-ton cylinders)

\begin{tabular}{|c|c|c|c|c|c|}
\hline Region & $\begin{array}{c}\text { Shown in } \\
\text { Fig. }\end{array}$ & Material & Density & $\begin{array}{c}\text { Model mass } \\
(\mathrm{kg})\end{array}$ & $\begin{array}{c}\text { Actual mass } \\
(\mathrm{kg})\end{array}$ \\
\hline \multicolumn{6}{|c|}{ 10-ton cylinder } \\
\hline 5 & 7 & Void & - & - & - \\
\hline 6 & 7 & $\mathrm{UF}_{6}$ & 5.1 & 9,555 & 9,539 \\
\hline 7 & 7 & Steel & 7.8212 & 1,580 & 2,041 \\
\hline 8 & 7 & Water or void & Variable & Variable & - \\
\hline \multicolumn{6}{|c|}{ 14-ton cylinder } \\
\hline 9 & 8 & Void & - & - & - \\
\hline 10 & 8 & $\mathrm{UF}_{6}$ & 5.1 & 12,527 & 12,501 \\
\hline 11 & 8 & Steel & 7.8212 & 1,976 & 2,359 \\
\hline 12 & 8 & Water or void & Variable & Variable & - \\
\hline \multicolumn{6}{|c|}{ Paducah Tiger } \\
\hline 17 & 9 & Void & - & - & - \\
\hline 18 & 9 & Steel & 7.8212 & 722 & NA \\
\hline 19 & 9 & Polyurethane & 0.087 & 674 & NA \\
\hline 20 & 9 & Steel & 7.8212 & 910 & NA \\
\hline
\end{tabular}

Table 6. Constituent material number density data (10- and 14-ton cylinders)

\begin{tabular}{|c|c|c|c|c|}
\hline Region & Material/Reference & $\begin{array}{l}\text { Density } \\
(\mathrm{g} / \mathrm{cc})\end{array}$ & Constituent & $\begin{array}{l}\text { Atom density } \\
\text { (atoms/b-cm) }\end{array}$ \\
\hline \multirow[t]{4}{*}{6,10} & \multirow[t]{4}{*}{ UF $/$ ref. 10} & \multirow[t]{4}{*}{5.1} & ${ }^{235} \mathrm{U}$ & $4.4168 \mathrm{E}-4$ \\
\hline & & & ${ }^{288} \mathrm{U}$ & $8.2860 \mathrm{E}-3$ \\
\hline & & & $\mathbf{F}$ & $5.3134 \mathrm{E}-2$ \\
\hline & & & $\mathbf{H}$ & $7.6800 \mathrm{E}-4$ \\
\hline \multirow[t]{2}{*}{$7,11,18,20$} & Carbon steel/ref. 5 & \multirow[t]{2}{*}{7.8212} & $\mathrm{Fe}$ & $8.3498 \mathrm{E}-2$ \\
\hline & SCALE standard composition & & C & $3.9250 \mathrm{E}-3$ \\
\hline \multirow{3}{*}{8,12} & Variable-density water/ & \multirow{3}{*}{$0.9982^{*}$} & & \\
\hline & ref. 5 & & $\mathbf{H}$ & $6.6751 \mathrm{E}-2^{*}$ \\
\hline & $\begin{array}{l}\text { SCALE standard } \\
\text { composition }\end{array}$ & & $\mathrm{O}$ & $3.3376 \mathrm{E}-2^{*}$ \\
\hline \multirow{5}{*}{19} & Polyurethane foam/ & \multirow{5}{*}{0.08654} & & \\
\hline & ref. 4 & & C & $1.7750 \mathrm{E}-3$ \\
\hline & & & $\mathrm{H}$ & $3.5500 \mathrm{E}-3$ \\
\hline & & & $\mathbf{N}$ & $5.9200 \mathrm{E}-4$ \\
\hline & & & $\mathrm{O}$ & $1.1830 \mathrm{E}-3$ \\
\hline
\end{tabular}

* Corresponds to full-density water. 
near unity SG. The peak value of $k_{\text {eff }}$ (see Figs. 10-11) for the 14-ton cylinder is $0.768 \pm 0.002$

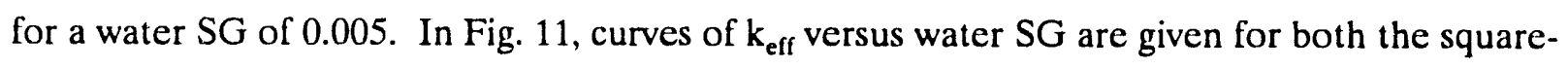
lattice pitch and a $7 \%$ reduced pitch. The $7 \%$ reduced case gives essentially identical results, $0.766 \pm 0.002$ versus $0.768 \pm 0.002$.

The results for the 10-ton cylinder are shown in Fig. 12, together with those for the 14ton cylinder. These are shown together since the 10- and 14-ton cylinders are the same radius, only differing cylinder lengths. The overall trends of the 14-ton cylinder can thus be expected to duplicate those of the 10-ton cylinder. For the water SG values shown, the 10- and 14-ton curves are very similar. The 14-ton $\mathrm{k}_{\text {eff }}$ values are expected to continue to be slightly larger than those of the 10-ton values since for high water densities, the infinite array $k_{\text {eff }}$ should approach the single unit $k_{\text {eff }}$. In Fig. $13, k_{\text {eff }}$ curves for the original radius versus a $7 \%$ reduced radius are given. The same characteristics as the $21 / 2$-ton and 14 -ton cylinders are seen. Here, the peak values are $0.769 \pm 0.002$ at an SG of 0.005 for the original radius and $0.763 \pm 0.002$ at an SG of 0.005 for the reduced radius.

\subsubsection{Infinite Array Results with Overpacks}

As stated earlier, only the 10-ton cylinder was analyzed with an overpack. This calculation, as before, was for an infinite array of packages with overpacks, 10-ton cylinder and Paducah Tiger overpack for this case. The $\mathrm{k}_{\text {eff }}$ value for an infinite array of 10-ton cylinders and overpacks is $0.547 \pm 0.002$. The overpack has an equivalent water SG of 0.05 . By comparing the $\mathrm{k}_{\text {eff }}$ value at an SG of 0.05 in Fig. 12 (approximately 0.63 ) with 0.547 , a difference of 0.08 $\Delta \mathrm{k}$ is seen. This represents a conservatism in the infinite array without overpack calculations.

\subsubsection{Single Unit Results}

The single unit models for the 10- and 14-ton $\mathrm{UF}_{6}$ cylinders consisted of the cylinder without an overpack surrounded by an effectively infinite water reflector. These values are used primarily as an internal consistency check on the infinite array results for an SG of 1.0. The single unit results are $0.526 \pm 0.002$ and $0.533 \pm 0.003$ for the 10 - and 14-ton cylinders, respectively. These two values are very nearly the same, as expected, since the 10 - and 14-ton cylinders are very similar in size. Comparing the 14-ton single unit result with the $\mathrm{k}_{\mathrm{eff}}$ at an SG of 1.0 in Fig. 10 also yields excellent agreement. 


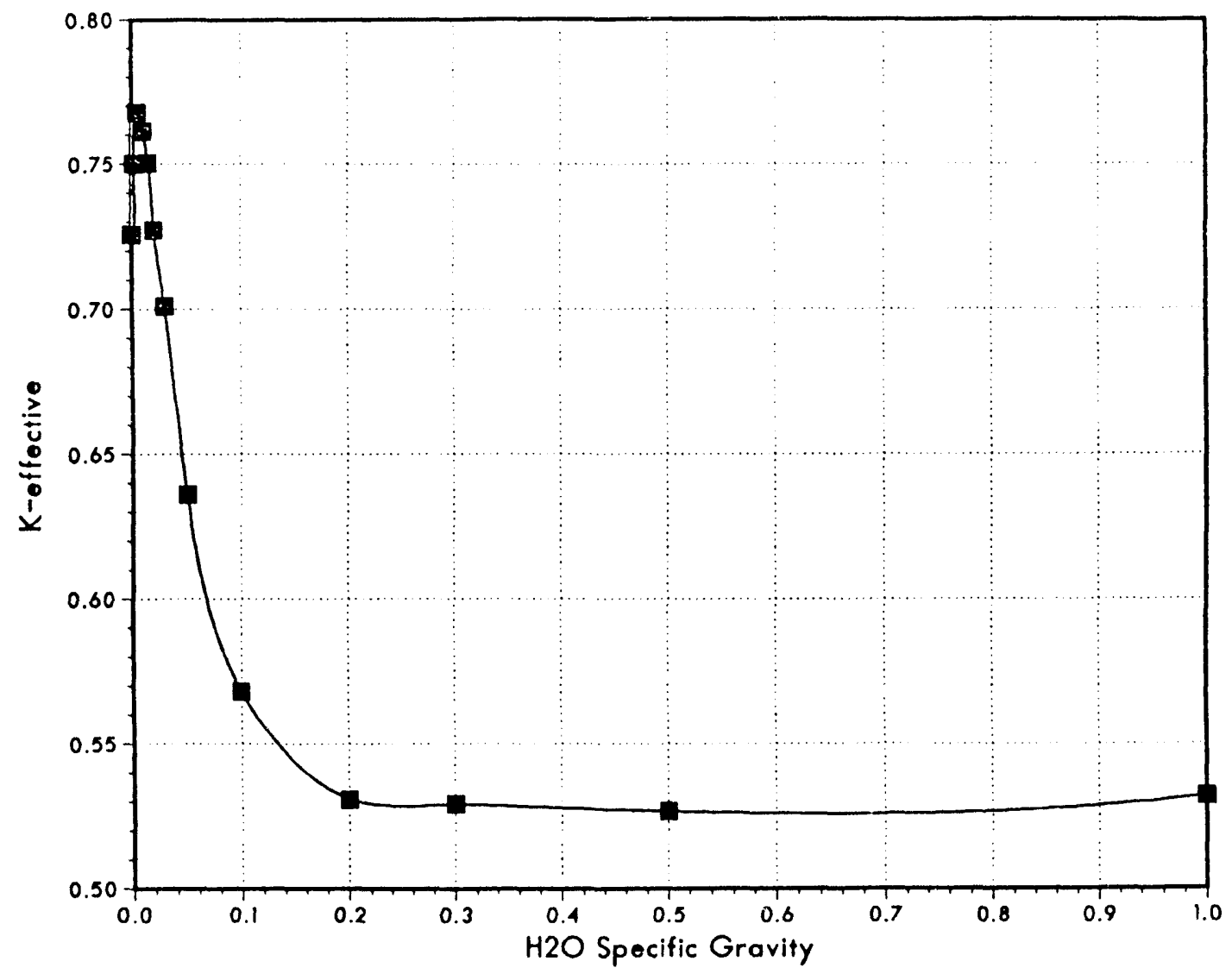

Fig. 10. Plot of $\mathrm{k}_{\mathrm{eff}}$ versus water specific gravity for infinite array of 14-ton $\mathrm{UF}_{6}$ cylinders (square-lattice, full-diameter model). 


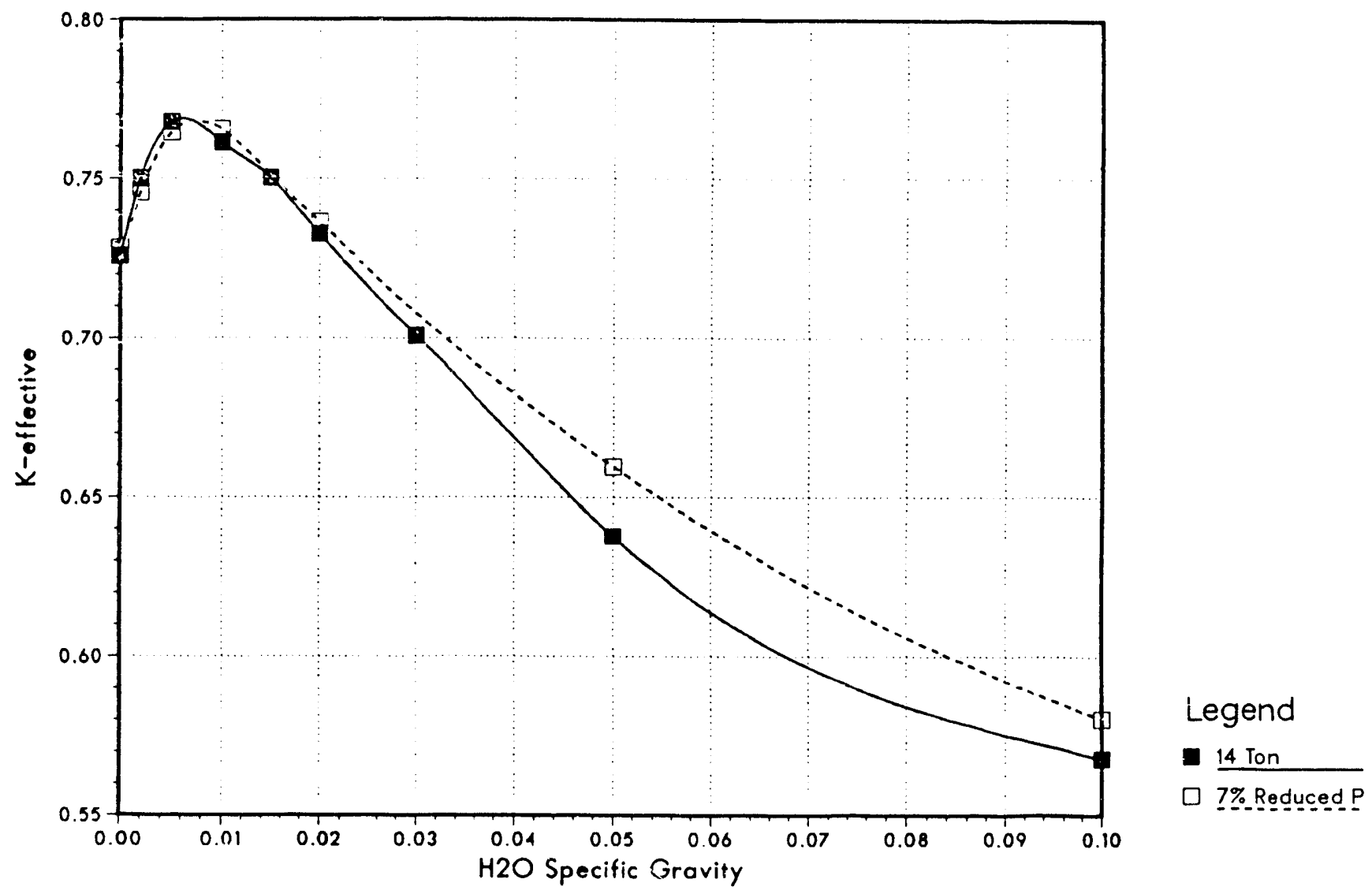

Fig. 11. Plot of $\mathbf{k}_{\text {eff }}$ versus water specific gravity for infinite array of 14-ton UF $_{6}$ cylinders for original and $7 \%$ reduced pitch case. 


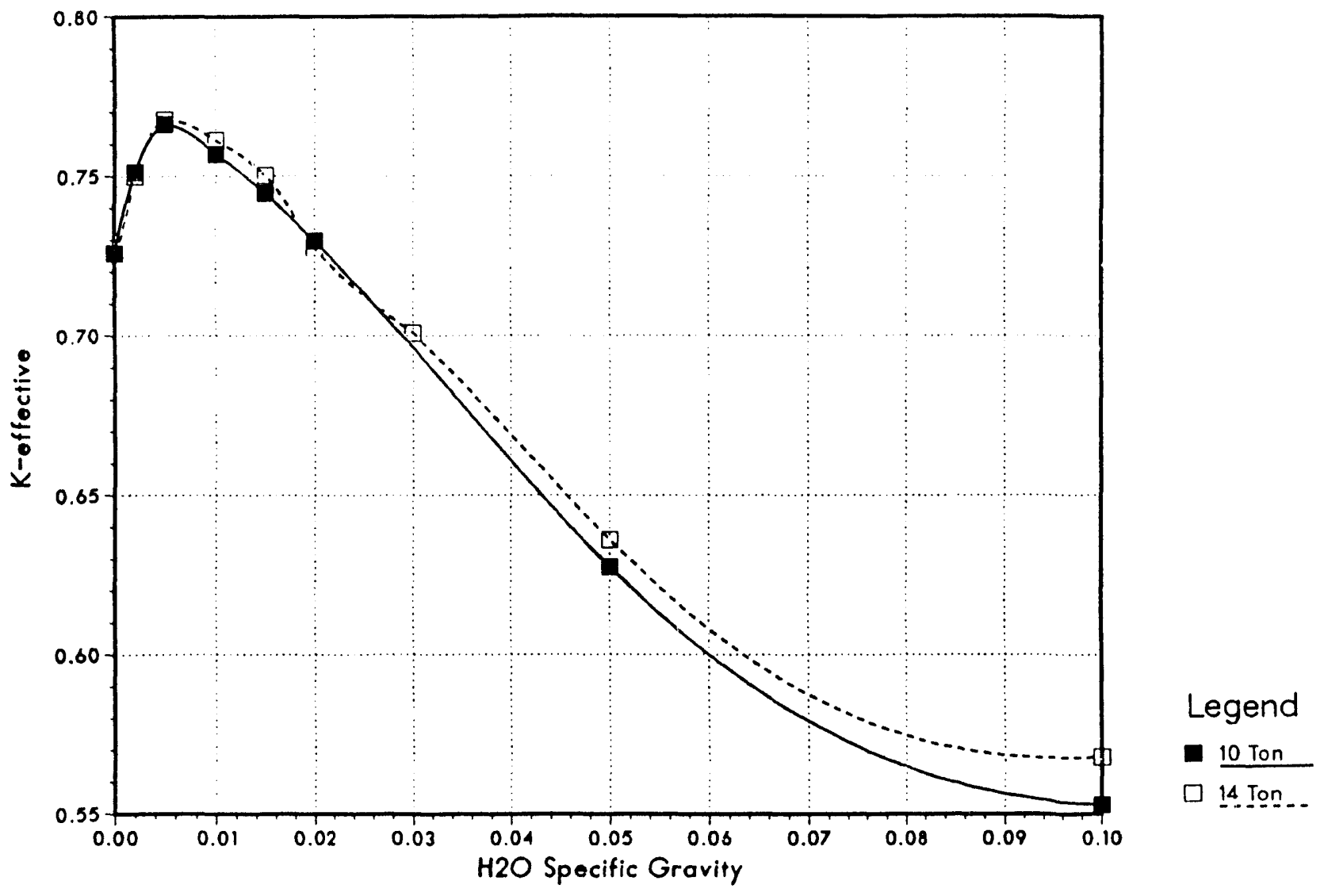

Fig. 12. Plot of $k_{\text {eff }}$ versus water specific gravity for infinite arrays of 10 - and 14-ton $U_{6}$ cylinders (square-lattice, full-diameter models). 


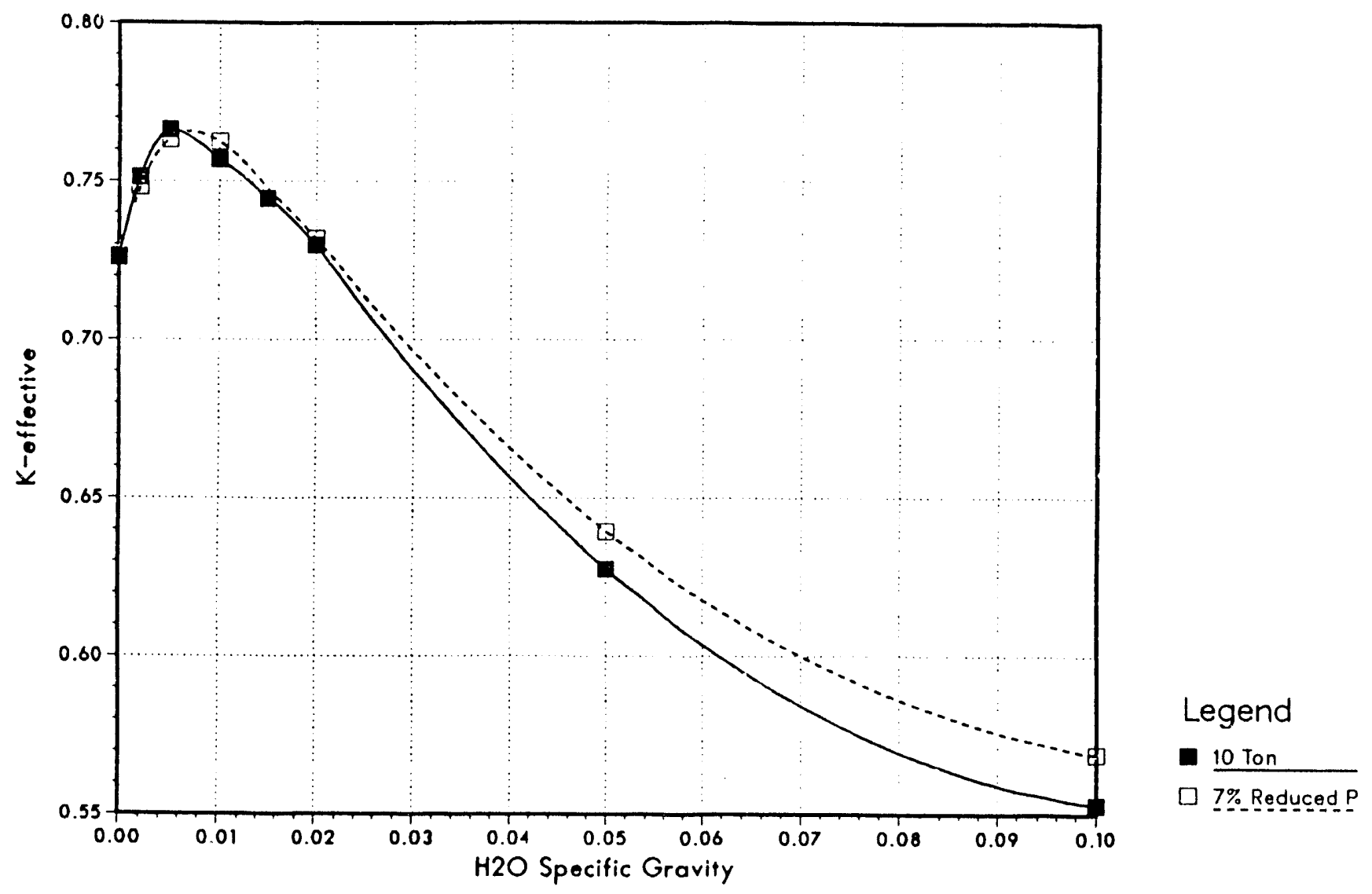

Fig. 13. Plot of $k_{\text {eff }}$ versus water specific gravity for infinite array of 10 -ton $U_{6}$ cylinders for original and $7 \%$ reduced pitch case. 


\subsubsection{Sensitivity Results}

The sensitivity calculations described in Sect. 3.2.4 for the $21 / 2$-ton cylinder were not repeated for the 10 - and 14 -ton cylinders. The conclusions for the $21 / 2$-ton cylinder included the insensitivity of $k_{\text {eff }}$ to temperature effects. The peak cylinder temperatures for the $21 / 2$-ton and 10 -ton fire tests were very nearly the same, assumed to be $65^{\circ} \mathrm{C}$ for this analysis. The extreme temperature of $-40^{\circ} \mathrm{C}$ is specified by the regulations. Also, the normal condition temperature

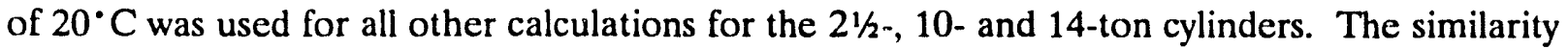
of cylinders and temperatures encountered should allow the temperature sensitivity conclusions from the $2 \frac{1}{2}$-ton analysis to be applied to the 10-ton analysis (the extreme temperature conditions apply only to cylinders with overpacks).

The fuel location sensitivity results generated in Sect. 3.2.4 should also be applicable to the 10- and 14-ton cylinders. Based on similar geometry arguments, the configurations with maximum $k_{\text {eff }}$ should again be models (c) and (d). The geometry corresponding to model (c) was used in the analysis of both the 10- and 14-ton cylinders.

\subsubsection{Validation Results}

The complete set of supporting results shown in Figs. 10-13 are given in Table 7. The table reports $k_{\text {eff }}$ values, water SG values, and AEG parameter values used for correlation to the lower safe limit of $k_{\text {eff }}$ as discussed in Sect. 2.3. The values of AEG given in the table range from 9 to 14. Over this range, in Fig. 1 the lower tolerance limit (subcritical limit) falls between 0.953 and 0.961 . For conservatism and convenience, the single value of 0.95 is chosen as the upper subcritical limit for $k_{\text {eff }}$ in this study. Thus, the acceptance criteria for the calculational results presented above are the reported $k_{\text {eff }}$ plus two standard deviations must be less than 0.95 , the upper subcritical limit.

\subsubsection{Summary}

The maximum $k_{\text {eff }}$ values for the conditions of optimal interstitial moderation with the premise of no water leakage into the $\mathrm{UF}_{6}$ cylinder are $0.768 \pm 0.002$ and $0.769 \pm 0.002$ for the 10 - and 14-ton cylinders, respectively. Applying a $2 \sigma$ safety margin yields corresponding $\mathrm{k}_{\text {eff }}$ values of 0.772 and 0.773 . Since these values represent peak reactivity, both the 10 - and 14-ton cylinders have a $k_{\text {eff }}$ less than the 0.95 upper subcritical limit criterion at all interstitial moderation conditions. These $\mathrm{k}_{\text {eff }}$ values should be insensitive to fuel location in the cylinder, 
Table 7. Tabulated results for various models of 10- and 14-ton cylinders

\begin{tabular}{|c|c|c|c|c|}
\hline Case & $k_{-\pi}$ & Std. dev. & Water SG" & $A E G^{\circ}$ \\
\hline \multicolumn{5}{|c|}{ Infinile array-aquare-lattice pilch } \\
\hline \multicolumn{5}{|c|}{ 10-ton results } \\
\hline UF40 & 0.553 & 0.002 & 0.1 & 12.7 \\
\hline UF39 & 0.628 & 0.003 & 0.05 & 13.7 \\
\hline UF38 & 0.730 & 0.002 & 0.02 & 13.8 \\
\hline UF42 & 0.745 & 0.002 & 0.015 & 13.5 \\
\hline UF46 & 0.756 & 0.002 & 0.01 & 12.8 \\
\hline UF44 & 0.769 & 0.002 & 0.005 & 11.6 \\
\hline UF45 & 0.755 & 0.002 & 0.002 & 10.4 \\
\hline UF36 & 0.726 & 0.002 & 0.0 & 9.3 \\
\hline \multicolumn{5}{|c|}{ 14-ton results } \\
\hline UF23 & 0.532 & 0.002 & 1.0 & 11.7 \\
\hline UF24 & 0.527 & 0.002 & 0.5 & 11.5 \\
\hline UF2S & 0.529 & 0.003 & 0.3 & 11.8 \\
\hline UF26 & 0.531 & 0.003 & 0.2 & 11.6 \\
\hline UF27 & 0.568 & 0.003 & 0.1 & 12.5 \\
\hline UF28 & 0.636 & 0.003 & 0.05 & 13.6 \\
\hline UF29 & 0.701 & 0.003 & 0.03 & 13.9 \\
\hline UF32 & 0.727 & 0.002 & 0.02 & 13.5 \\
\hline UF33 & 0.750 & 0.002 & 0.015 & 13.3 \\
\hline UF31 & 0.761 & 0.002 & 0.01 & 12.6 \\
\hline UF34 & 0.768 & 0.002 & 0.005 & 11.4 \\
\hline UF35 & 0.750 & 0.002 & 0.002 & 10.2 \\
\hline UF30 & 0.726 & 0.001 & 0.0 & 9.2 \\
\hline \multicolumn{5}{|c|}{ Infinite array-7\% roducod pitch } \\
\hline \multicolumn{5}{|c|}{ 10-ton results } \\
\hline UF58 & 0.569 & 0.003 & 0.1 & 12.9 \\
\hline UF57 & 0.732 & 0.002 & 0.02 & 13.6 \\
\hline UF56 & 0.762 & 0.002 & 0.01 & 12.6 \\
\hline UF55 & 0.763 & 0.002 & 0.005 & 11.3 \\
\hline UF54 & 0.748 & 0.002 & 0.002 & 10.1 \\
\hline UF53 & 0.726 & 0.002 & 0.0 & 9.3 \\
\hline \multicolumn{5}{|c|}{ 14-ton results } \\
\hline UFS2 & 0.581 & 0.003 & 0.1 & 12.8 \\
\hline UF51 & 0.737 & 0.002 & 0.02 & 13.3 \\
\hline UF50 & 0.766 & 0.002 & 0.01 & 12.4 \\
\hline UF49 & 0.764 & 0.002 & 0.005 & 11.2 \\
\hline UF48 & 0.746 & 0.002 & 0.002 & 10.0 \\
\hline \multirow[t]{2}{*}{ UF47 } & 0.728 & 0.002 & 0.0 & 9.3 \\
\hline & \multicolumn{4}{|c|}{ Overpact amry reaults } \\
\hline \multicolumn{5}{|c|}{ 10-ton result } \\
\hline UF02 & 0.547 & 0.002 & 0.05 & 11.2 \\
\hline \multicolumn{5}{|c|}{ Single unit-infinite $\mathrm{H}_{2} \mathrm{O}$ relloction } \\
\hline \multicolumn{5}{|c|}{ 10-ton result } \\
\hline UF60 & 0.526 & 0.002 & 1.0 & 11.9 \\
\hline \multicolumn{5}{|c|}{ 14-ton result } \\
\hline UF61 & 0.533 & 0.003 & 1.0 & 11.8 \\
\hline
\end{tabular}

-Specific gravity.

-Average energy group causing fission. 
cylinder spacing, and temperature effects. These final $k_{\text {eff }}$ values correspond to an infinite array of optimal interstitially moderated cylinders. Thus, the 10-ton UF 6 cylinder should meet both the accident and normal conditions for a Fissile Class $I(T I=0)$ cylinder with $5.0 \mathrm{wt} \%{ }^{235} \mathrm{U}$ enrichment. These results also indicate that the 14-ton cylinder should be able to accommodate an increase in enrichment from $4.5 \mathrm{wt} \%$ to $5 \mathrm{wt} \%$ for on-site operations.

These final calculations should be conservative due to the neglect of the overpack materials. The degree of conservatism has been estimated at $12 \%$ for the 10 -ton cylinder.

Based on this evaluation, the 10-ton $\mathrm{UF}_{6}$ cylinder with 5 wt $\%{ }^{235} \mathrm{U}$ enrichment meets the 10 CFR. 71 criteria for a Fissile Class I package with a TI of zero for criticality purposes; however, TI may be required based on radiation from the packages.

\section{REFERENCES}

1. "Part 71-Packaging and Transportation of Radioactive Material," 10 CFR.71, Code of Federal Regulations 10, 195 (Revised as of January 1, 1990).

2. A. J. Mallett, C. E. Newlon, Protective Shipping Packages for 30-Inch-Diameter UF 6 Cylinders, K-1686, Union Carbide Corp., Nucl. Div., Oak Ridge Gaseous Diffusion Plant (April 1967).

3. Union Carbide Corp., Nucl. Div., Internal Correspondence, Approvals Committee in Nuclear Safety to ORGDP Nuclear Safety Committee, May 19, 1969.

4. D. H. Stitt, Safety Analysis Report on the "Paducah Tiger" Protective Overpack for 10-Ton Cylinders of Uranium Hexafluoride, KY-669, Union Carbide Corporation, Nuclear Division, Paducah Gaseous Diffusion Plant (June 1975).

5. SCALE: A Modular Code System for Performing Standardized Computer Analyses for Licensing Evaluation, Vols. I-III, NUREG/CR-0200, Rev. 4 (ORNL/NUREG/CSD2/R4), Vols. I-III (draft February 1990). Available from Radiation Shielding Information Center as CCC-545.

6. W. C. Jordan, N. F. Landers, and L. M. Petrie, Validation of KENO V.a Comparison with Critical Experiments, ORNL/CSD/TM-238 (December 1986).

7. W. C. Jordan, SCALE-4 27-Neutron Group ENDF/B-IV Based Cross-Section Library Validation (to be published). 
8. H. R. Dyer, W. C. Jordan, and V. R. Cain, "A Technique for Code Validation for Criticality Safety Calculations," to be published in Proceedings of American Nuclear Society Meeting, held in Orlando, Florida, June 1991.

9. Union Carbide Corporation, Nuclear Division, Internal Correspondence, "Voids in $\mathrm{UF}_{6}$ Cylinders," M. G. Otey to C. W. Walter, February 24, 1971.

10. Uranium Hexafluoride: Handling Procedures and Container Descriptions, ORO-651 (Rev. 5), U.S. Department of Energy (September 1987).

11. USDOE Material and Equipment Specification SP-9, Rev. 1. 


\section{INTERNAL DISTRIBUTION}

1. S. M. Bowman

2. M. C. Brady

3-7. B. L. Broadhead

8. H. L. Dodds

9-13. H. R. Dyer

14. C. M. Hopper

15. J. W. Insalaco

16. W. C. Jordan

17. V. S. McCauley

18. L. F. Norris

19. C. V. Parks

20. L. M. Petrie

21. R. R. Rawl

22. J.-P. Renier

23. C. H. Shappert
24. L. B. Shappert

25. G. R. Smolen

26. R. Stachowiak

27. W. C. Stoddart

28. J. S. Tang

29. J. C. Turner

30. M. J. Welch

31. B. W. Welles

32. R. M. Westfall

33. G. E. Whitesides/R. P. Leinius

34-35. Laboratory Records Dept.

36. Laboratory Records, ORNL-RC

37. Document Reference Section

38. Central Research Library

39. ORNL Patent Section

\section{EXTE:RNAL DISTRIBUTION}

40. D. M. D'Aquila, Martin Marietta Energy Systems, Inc., Nuclear Criticality Safety, P.O. Box 628, MS 2213, Piketon, Ohio 45661

41. J. W. Bennett, DOE Field Office, Oak Ridge, P.O. Box 2001, Oak Ridge, TN 37831

42. M. Bennett, DOE Field Office, Oak Ridge, P.O. Box 2001, Oak Ridge, TN 37831

43. L. Blalock, Nuclear Materials Transportation R\&D, U.S. Department of Energy, EM, Washington, DC 20545

44. R. A. Boelens, Martin Marietta Energy Systems, Inc., P.O. Box 628, Bldg. X344a, MS 4018, Piketon, Ohio 45661

45. W. Carriker, Radioactive Materials Branch, Office of Hazardous Materials Transportation, U.S. Department of Transportation, 400 7th Street S.W., Washington, DC 20590

46. C. 1 Caves, U.S. Department of Energy, Waslington, DC 20545

47. R. Chappell, Transportation Branci, Office of Nuclear Material Safety \& Safeguards, U.S. Nuclear Regu'atory Commission, MS WF1, Washington, DC 20555

48. R. N. Collier, DOE Field Office, Oak Ridge, P.O. Box 2001, Oak Ridge, TN 37831

49. R. H. Dyer, DOE Field Office, Oak Ridge, P.O. Box 2001, Oak Ridge, TN 37831

50. E. P. Easton, Transportation Branch, Office of Nuclear Material Safety \& Safeguards, U.S. Nuclear Regulatory Commission, MS WF1, Washington, DC 20555

51. D. Edmundson, Westinghouse Electric Corp., Nuclear Fuels Div., P.O. Box 5906, Columbia, SC 29250 
52. F. P. Falci, Manager, Nuclear Materials Transportation R\&D, U.S. Department of Energy, EM-51, Washington, DC 20545

53. A. S. Garcia, Argonne National Laboratory, Fuel Cycle Division, P.O. Box 2528, ANL-W, Bldg. 765-A, Idaho Falls, ID 83403-2528

54. R. F. Garrison, Nuclear Materials Transportation R\&D, U.S. Department of Energy, EM-51, $:$;chington, DC 20545

55. B. Hook, Paducah Gaseous Diffusion Plant, P. O. Box 1410, Paducah, KY 42001

56. D. R. Hopkins, Transportation Branch, Office of Nuclear Material Safety \& Safeguards, U.S. Nuclear Regulatory Commission, MS WF1, Washington, DC 20555

57. W. R. Householder, Nuclear Container, Inc., 1410 Strawberry Lane, Johnson City, TN 37604

58. J. Huffer, Paducah Gaseous Diffusion Plant, P.O. Box 1410, Bldg. C-743, Paducah, KY 42001

59. W. Jackson, Advanced Nuclear Corp., P.O. Box 130, Richland, WA 99352

60. F. Kovac, Martin Marietta Energy Systems, Inc., P.O. Box 628, Piketon, OH 45661

61. C. E. MacDonald, Transportation Branch, Office of Nuclear Material Safety \& Safeguards, U.S. Nuclear Regulatory Commission, MS WF1, Washington, DC 20555

62. R. Miller, Combustion Engineering, Inc., P.O. Box 107, Hematite, MO 63047

63. T. S. Needels, U.S. Department of Energy, EH, Washington, DC 20545

64. R. Newvahner, Martin Marietta Energy Systems, Inc., P.U. Rox 528, MS 2210-A, Piketon, $\mathrm{OH} 45661$

65. W. A. Pryor, PAI Corporation, 116 Milan Way, Oak Ridge, TN 37830

66. F. Punch, Chief, Packaging Certification Program, Division of Quality Verification and Transportation, U.S. Department of Energy, MS EH-321, Washington, DC 20545

67. R. I. Reynolds, Paducah Gaseous Diffusion Plant, P.O. Box 1410, Bldg. C100, Paducah, KY 42001

68. J. Russell, DOE Field Office, Oak Ridge, P.O. Box 2001, Oak Ridge, TN 37831

69. D. C. Thomas, Manager, Gaseous Diffusion Operations, Office of Uranium Enrichment, U.S. Department of Energy, MS NE-33, Washington, DC 20545

70. J. T. Thomas, 16 Laurel Place, Norris, TN 37828-0296

71. M. Wangler, Chief, Radioactive Materials Branch, Office of Hazardous Materials Transportation, U.S. Department of Transportation, 400 7th Street, S.W., Washington, DC 20590

72. L. D. Williams, Martin Marietta Energy Systems, Inc., P.O. Box 628, Bldg. X-100, Piketon, Ohio 45661

73. C. J. Withee, Transportation Branch, Office of Nuclear Material Safety \& Safeguards, U.S. Nuclear Regulatory Commission, MS WF1, Washington, DC 20555

74. J. Zidak, General Electric-Nuclear, P.O. Box 780, Wilmington, NC 28402

75-84. Office of Scientific and Technical Information, U.S. Department of Energy, P.O. Box 62, Oak Ridge, TN 37831

85. Office of Assistant Manager for Energy Research and Development, DOE Field Office, Oak Ridge, P.O. Box 2008, Oak Ridge, Tr' 37831 

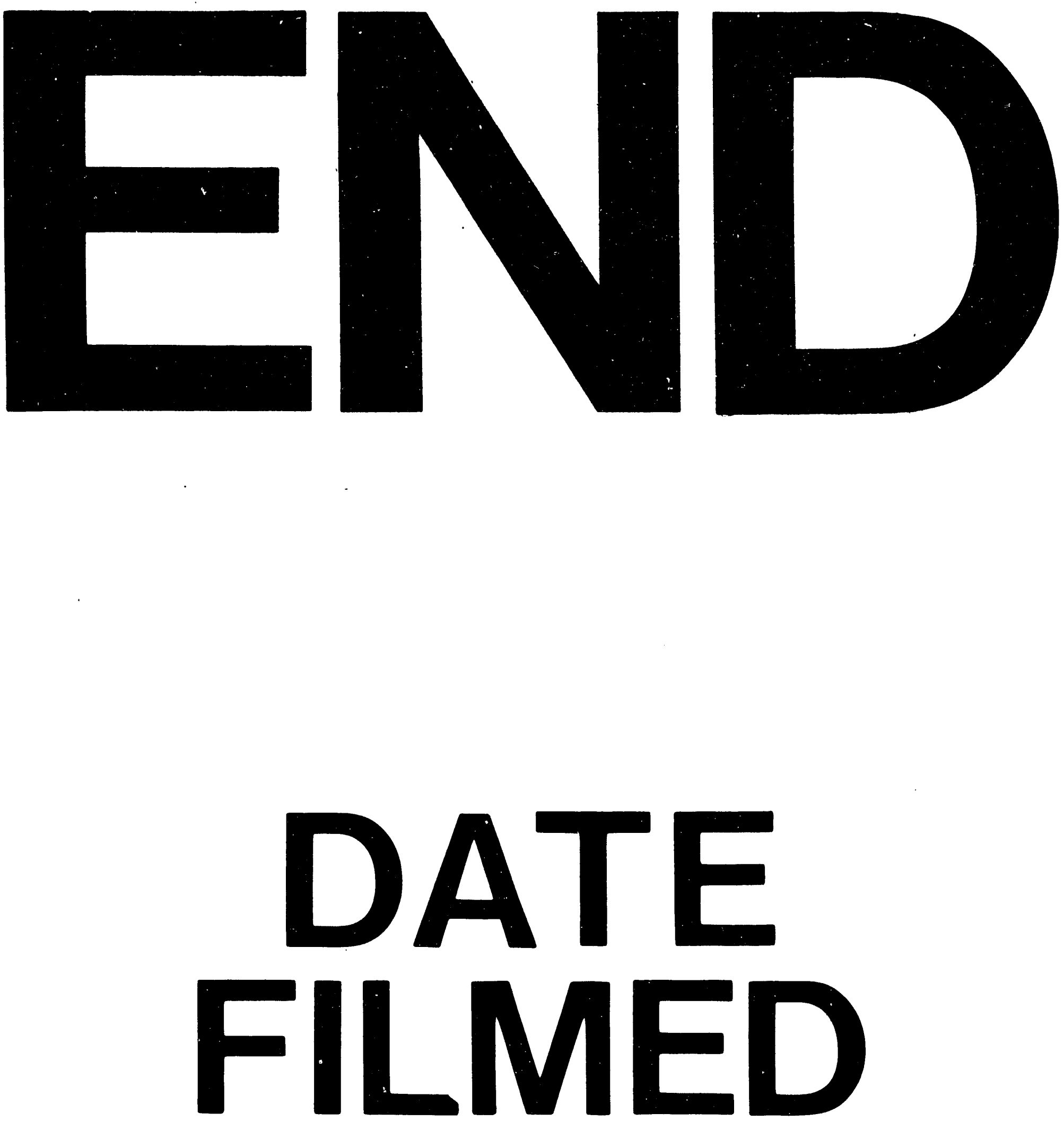

1

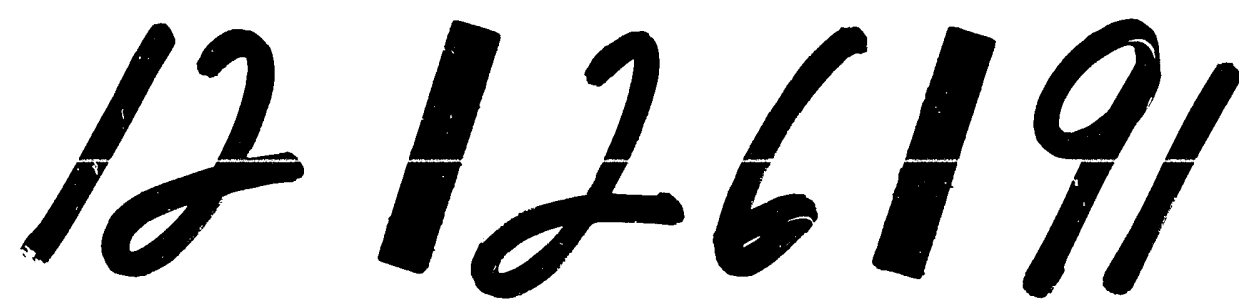


